\title{
Enzymatic Hydrolysis of Lignocellulosic Biomass Using an Optimized Enzymatic Cocktail Prepared From Secretomes of Filamentous Fungi Isolated From Amazonian Biodiversity
}

\section{Pamella Santa Rosa ( $\nabla$ pamellasuely@gmail.com )}

Federal University of Amazonas: Universidade Federal do Amazonas https://orcid.org/0000-00021356-5735

\section{Jessica Batista de Oliveira}

Federal University of Amazonas: Universidade Federal do Amazonas

Spartaco Astolfi Filho

Federal University of Amazonas: Universidade Federal do Amazonas

Nei Pereira Jr.

Federal University of Rio de Janeiro: Universidade Federal do Rio de Janeiro

\section{Research Article}

Keywords: lignocellulolytic fungi, enzymatic cocktail, lignocellulosic biomass, hydrolysis

Posted Date: April 29th, 2021

DOI: https://doi.org/10.21203/rs.3.rs-460730/v1

License: (c) (1) This work is licensed under a Creative Commons Attribution 4.0 International License. Read Full License

Version of Record: A version of this preprint was published at Applied Biochemistry and Biotechnology on August 19th, 2021. See the published version at https://doi.org/10.1007/s12010-021-03642-5. 


\section{Enzymatic hydrolysis of lignocellulosic biomass using an optimized enzymatic cocktail prepared from secretomes of filamentous fungi isolated from Amazonian biodiversity}

Pamella Suely Santa Rosa Pimentel ${ }^{1}$; Jessica Batista de Oliveira ${ }^{1}$ Spartaco Astolfi Filho $^{2}$; Nei Pereira Jr. ${ }^{3}$

${ }^{1}$ Multi Institutional Biotechnology Graduate Program, Federal University of Amazonas, Manaus, 69067-005, Brazil

${ }^{2}$ Centro de Apoio Multidisciplinar (CAM), Federal University of Amazonas, Manaus, 69067005, Brazil

${ }^{3}$ Laboratory of Bioprocess Development - Center of Biofuels, Oil and Derivatives, School of Chemistry, Federal University of Rio de Janeiro, Rio de Janeiro, 21941-594, Brazil

\section{Abstract}

The use of lignocellulosic biomass (LCB) has emerged as one of the main strategies for generating renewable biofuels. For the efficient use of such feedstock, pretreatments are essential. The hydrolysis of cellulose - major component of LCB - demands enzymatic cocktails with improved efficiency to generate fermentable sugars. In this scenario, lignocellulolytic fungi have enormous potential for the development of efficient enzyme platforms. In this study, two enzymatic cocktails were developed for hydrolysis of two lignocellulosic biomasses: industrial cellulose pulp and cassava peel. The solid biomass ratio in relation to the protein content of the enzyme cocktail were performed by experimental design. The optimized cocktail for the hydrolysis of cellulose pulp (AMZ 1) was composed, in protein base, by $43 \%$ of Aspergillus sp LMI03 enzyme extract and $57 \%$ of $T$. reesei QM9414, while the optimal enzyme cocktail for cassava peel hydrolysis (AMZ 2) was composed by $50 \%$ of Aspergillus sp LMI03 enzyme extract, $25 \%$ of the extract of $P$. citrinum LMI01 and $25 \%$ of $T$. reesei. The ratio between solids and protein loading for AMZ 1 cocktail performance was $52 \mathrm{~g} / \mathrm{L}$ solids and $30 \mathrm{mg}$ protein $/ \mathrm{g}$ solids, resulting in a hydrolytic efficiency of $93 \%$. For the AMZ 2 cocktail, the hydrolytic efficiency was $78 \%$ for an optimized ratio of $78 \mathrm{~g} / \mathrm{L}$ solids and $19 \mathrm{mg}$ protein $/ \mathrm{g}$ solids. These results indicate that cocktails formulated with enzymatic extracts of $P$. citrinum LMI01, Aspergillus sp LMI03 and T. reesei QM9414 are excellent alternatives for efficient hydrolysis of plant biomass and for other processes that depend on biocatalysis.

Keywords lignocellulolytic fungi, enzymatic cocktail, lignocellulosic biomass, hydrolysis. 


\section{Introduction}

The issues related to the step of lingnocellulosic biomass saccharification remain one of the main factors that determine the performance and cost of cellulosic ethanol, the so called second generation (2G) ethanol. Therefore, much research has been devoted to increasing the enzymatic saccharification efficiency seeking a cheaper production of bioethanol [1] [2]. Researches with strains of Trichoderma reesei were pioneered in the design of enzymatic cellulose saccharification by a synergistic combination of different cellulase activities [3]. Of the species of Trichoderma sp isolated during World War II and subsequently analyzed by the researchers Mary Mandels and Ewyn Reese, the QM6 strain (sixth of the 6 fungus cultures of the genus Trichoderma) from the Quartemaster collection (US Army Quartermaster Research and Development Center), presented an excellent cellulose degradation capacity. This strain is considered a reference of Trichoderma reesei and from which all mutant strains that are used today in the industry were derived [4], as $T$. ressei QM9414 and Rut 30; the latter produces cellulases 2 to 4 times more than the original strain QM6a [5]. The formulations of commercial enzymes widely known and used industrially are produced with $T$. reesei enzymes. According to Bischof et al. (5), the filamentous fungus T.reesei still represents great importance in the research, it has been that on average more than 100 articles related to this fungus are published annually[4].

The hydrolysis of biomass to fermentable sugars by biological pathway, requires the action of multiple enzymes with different specificities to deconstruct the lignocellulosic structure of plant biomass [1][6]. The classic model of enzymatic degradation of cellulose is described by a set of enzymes belonging to the group of glycosil hydrolases $(\mathrm{GH})$ that act synergistically to hydrolyze the cellulose fiber. However, it is currently known that other proteins that do not belong to the GH family, act in a way to cooperate with the catalytic power of cellulases, thus increasing the efficiency of hydrolyzing lignocellulosic materials and generating fermentable sugars [7][8]. These proteins called accessory proteins were classified within the AA (Auxiliary activity) family and the main ones contributed to the degradation of lignocellulose are: polysaccharide lytic monoxygenases (LPMOs) and swollenins [9].

The action of LPMO's is influenced by the presence of cellobiose dehydrogenases ( $\left.\mathrm{CDH}^{\prime} \mathrm{s}\right), \mathrm{CDH}$ are fungal hemoflavoenzymes that belong to the oxidoreductase superfamily, and catalyze the oxidation of two cellobiose electrons [10]. It has been described that $\mathrm{CDHs}$ are secreted by filamentous fungi in conditions of cellulose degradation, and act in conjunction with LPMOs, increasing the conversion of cellulose to glucose [8]. LPMOs act in the crystalline region of cellulose, generating oxidized and non-oxidized chain ends and require an external electron donor to induce its activity [9]. While, swollenins have disruptive activity on various cellulosic substrates, such as filter paper, cotton and plant cell walls, without, however, releasing detectable amounts of sugars [11]. Enzymes that degrade lignin may not act on carbohydrates, but, because lignin is invariably and closely associated with 
carbohydrates in the cell wall of plants, lignolytic enzymes cooperate with classic polysaccharides enzymes [9].

The challenge for the production of ethanol and other chemicals using lignocellulosic biomass is due to the recalcitrant nature of biomass and technical difficulties of the process, such as: type of pre-treatment, balance of enzymatic cocktails, microorganisms used, conditions of the fermentative process and type of bioreactor configurations [6]. Thus, obtaining high levels of fermentable sugars from lignocellulosic biomass depends on the efficient production of enzymes and well-balanced enzymatic cocktails containing: cellulases, hemicellulases, and other accessory proteins that act synergistically [12]. The optimization of enzyme mixtures to improve hydrolysis is among the factors that will allow further advances in the area of second generation technologies, adding to a greater understanding of the interactions between enzymes and lignocellulosic substrates and the development of enzyme engineering [13]. In this sense, the studies of proteins involved in the degradation of lignocellulosic material have allowed a broader knowledge of the main proteins of the hydrolytic complex that can be applied in processes inserted in the context of biorefinery. [14] [15] [2].

The synergistic action between hydrolases, especially cellulases and hemicellulases, and between lytic polysaccharide monooxygenases, swolenins and other auxiliary proteins in the pre-treated material, is extremely necessary for the effective deconstruction of biomass [12]. Strains of filamentous fungi of the species $T$. reesei have an effective cellulase production system (endoglucanases and exoglucanases), but with a very low production of $\beta$-glucosidases, while the Aspergillus genus are described for producing high levels of $\beta$-glucosidase, key-enzymes in glucose production [16] [17]. The prepared commercial of cellulases, Multifect $\AA$, was complemented with Penicillium funiculosum and Trichoderma harzianum enzymatic complexes, displaying greater efficiency than when used alone; in this case, the higher hydrolytic efficiency was correlated with an adequate level of $\beta$-glucosidase and xylanase activities [18].

Other studies have highlighted the need to complement enzymatic preparations with enzymes from different sources, as well as added accessory proteins that take part in the cellulose amorphogenesis [14][8]. Thus, the objective of this work was to produce enzymatic cocktails of high catalytic performance using fungal platforms isolated from the Amazon region: Penicillium citrinum LMI01 and Aspergillus sp LMI03 together with the hydrolytic complex of a strain of Trichoderma reesei QM9414.

\section{Materials and Methods}

\section{Microorganisms}

For the production of enzymatic extracts used to formulate the cocktails composition, the filamentous fungi were used: Trichoderma reesei QM9414 
obtained from the Tropical Culture Collection of the André Tosselo Foundation (Campinas, São Paulo, Brazil); Penicillium citrinum strain LMI01 (NCBI access code: NoKU686951), isolated from decaying plant material [19], and Aspergillus sp strain LMI03 (NCBI access code: No. MT989354) isolated from recycled cellulose pulp (unpublished data). For all experiments, a pre-inoculum for mycelial growth of each fungus was prepared from cultures reactivated in BDA (Potato Dextrose agar) with a maximum of 10 days of growth. Spore suspensions for the pre-inoculum were made in sterilized distilled water, followed by spore counting in a Neubauer chamber.

\section{Enzymatic production}

The enzymatic extracts of the filamentous fungi $P$. citrinum LMI01, Aspergillus sp. LMI03 and T. reesei QM9414 were obtained by submerged fermentation that was conducted using industrial cellulose pulp as a carbon source. For production of cellulases by T. reesei QM9414, Mandels medium [20] was used composed of: $\mathrm{KH}_{2} \mathrm{PO}_{4}(2.0 \mathrm{~g} / \mathrm{L}) ; \mathrm{CaCl}_{2} 2 \mathrm{H}_{2} \mathrm{O}(0.4 \mathrm{~g} / \mathrm{L}) ; \mathrm{MgSO}_{4} 7 \mathrm{H}_{2} \mathrm{O}(0.3 \mathrm{~g} / \mathrm{L})$; $\left(\mathrm{NH}_{4}\right)_{2} \mathrm{SO}_{4}(1.4 \mathrm{~g} / \mathrm{L})$; urea $(0.3 \mathrm{~g} / \mathrm{L})$; peptone $(1.0 \mathrm{~g} / \mathrm{L})$; yeast extract $(0.25 \mathrm{~g} / \mathrm{L})$; $\mathrm{FeSO}_{4} 7 \mathrm{H}_{2} \mathrm{O}(5 \mathrm{mg} / \mathrm{L}) ; \mathrm{MnSO}_{4} 7 \mathrm{H}_{2} \mathrm{O}(1.6 \mathrm{mg} / \mathrm{L}) ; \mathrm{ZnSO}_{4} 7 \mathrm{H}_{2} \mathrm{O} \quad(1.4 \mathrm{mg} / \mathrm{L})$ and $\mathrm{CoCl}_{2} 6 \mathrm{H}_{2} \mathrm{O}(2 \mathrm{mg} / \mathrm{L})$, added $15 \mathrm{~g} / \mathrm{L}$ of cellulosic carbon source. For the production of enzymes by Penicillium citrinum LMI01, a medium previously optimized for this strain was used, composed of: $\mathrm{MgSO}_{4}: 0.10 \mathrm{~g} / \mathrm{L}, \mathrm{KH}_{2} \mathrm{PO}_{4}$ : $12 \mathrm{~g} / \mathrm{L}$; Urea: $0.25 \mathrm{~g} / \mathrm{L}$ and peptone $1.32 \mathrm{~g} / \mathrm{L}$, cellulosic carbon source: $15 \mathrm{~g} / \mathrm{L}$, and for enzyme production by Aspergillus sp LMI03 the medium optimized for this strain was composed of: cellulosic carbon source: $15 \mathrm{~g} / \mathrm{L}, \mathrm{CaCl}_{2}: 0.15 \mathrm{~g} / \mathrm{L}$,

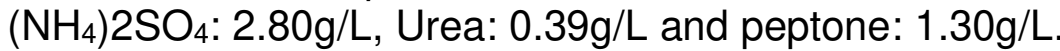

The cultivation of each filamentous fungus was carried out in three replicates, by submerged fermentation in $500 \mathrm{~mL}$ Erlenmeyer flasks containing $200 \mathrm{~mL}$ of medium. The flasks were inoculated with $10 \%(\mathrm{v} / \mathrm{v})$ culture containing cells previously grown (pre-inoculum) and incubated at $30^{\circ} \mathrm{C}, 200 \mathrm{rmp}$, for $72 \mathrm{~h}$. After fermentation, the mycelial mass was removed by vacuum filtration on glass wool. Then, mycelium-free culture supernatants were subjected to a tangential filtration system (QuixStand $\AA$-GE), using Hollow-fiber cartridges.

A volume of 4 liters of each supernatant was applied in cut-off cartridge $0.1 \mu \mathrm{m}$ (microfiltration) for removal of remaining cells and clarification, and then, was applied in cut-off cartridge 3kDa (ultrafiltration), the working conditions were: cartridge inlet pressure up to 10 and $15 \mathrm{Psi}$, respectively. The volume permeated in the ultrafiltration was neglected and the volume withheld $(40 \mathrm{~mL})$ was recovered. The enzymatic activities and the total protein content in the permeate and in the withheld were monitored during the process.

\section{Electrophoretic profile of proteins and enzymatic activity in gel SDS- PAGE}

The electrophoretic profile of the proteins present in the concentrated enzymatic extracts of the fungi P. citrinum LMI01, Aspergillus sp LMI03 and T. reesei were analyzed on SDS/PAGE gel (12\% polyacrylamide) prepared as 
described by Laemmli [21]. At the same time, a zymogram for cellulases was performed on SDS-PAGE gel copolymerized with $0.2 \%$ carboxymethyl Cellulose (CMC). The samples were prepared in denaturing buffer (0.2 M Tris$\mathrm{HCl} \mathrm{pH} \mathrm{6.8;} \mathrm{4 \%} \mathrm{(v/v)} \mathrm{SDS;} \mathrm{20 \%} \mathrm{(v/v)} \mathrm{glycerol;} \mathrm{0.1 \%} \mathrm{(p/v)} \mathrm{bromophenol}$ blue) without $\beta$-mercaptoethanol. Electrophoresis was performed in $50 \mathrm{~mA}$, 200W Tris-glycine buffer for approximately $1 \mathrm{~h} 30 \mathrm{~min}$.

After electrophoresis, the SDS-PAGE gel was stained with Coomassie blue R250 overnight and discolored by incubating the gel in a bleach solution containing $50 \%$ methanol and $12 \%$ acetic acid, until visualization of the protein. While the zymogram gel was incubated in $1 \%(\mathrm{v} / \mathrm{v})$ Triton X-100 buffer under slight agitation for 1 hour to remove the SDS and renaturate the proteins. Then, the gel was washed in distilled water and incubated in reaction buffer (sodium citrate $\mathrm{pH} 4.850 \mathrm{mM}$ ) for 1 hour. In the sequence, the gel was incubated in Congo Red $0.1 \%$ solution with shaking for 20 minutes, and then, decolored in $1 \mathrm{M} \mathrm{NaCl}$ solution, until the appearance of clear bands against the red background indicating the degradation of $\mathrm{CMC}$, for a better visualization of the degradation halos was added 100uL of glacial acetic acid [22].

\section{Enzymatic hydrolysis}

Industrial cellulose pulp, provided by the company Benaion Indústria de Papel e Celulose S.A., and cassava peel (Manhiot esculenta Crantz), obtained in the municipal market of Manaus-AM-Brazil were used for the enzymatic hydrolysis assays. First, the cassava peel was crushed and passed through a decontamination process (washing, drying in an oven at $100^{\circ} \mathrm{C}$, autoclaved at $120^{\circ} \mathrm{C}$ for $60 \mathrm{~min}$, drying at $100^{\circ} \mathrm{C} 24$ hours) to remove possible contaminants. These biomasses were quantified in terms of cellulose, hemicellulose, lignin and ash content, using the methodology described by the National Renewable Energy Laboratory-NREL (33) and Ververis et al. (34).

The hydrolysis experiments were carried out according to the methodologies described by Barcelos et al. [23], with modifications. The hydrolysis was carried out using industrial cellulose pulp and cassava peel as solid substrates, in separate experiments. The proportion of solid waste was $25 \mathrm{~g} / \mathrm{L}$, in a reaction volume of $1 \mathrm{~mL}$, in $2 \mathrm{~mL}$ eppendorf tubes. The volumes of the concentrated enzymatic extracts were added to the tubes according to the protein concentration of each one, so that it had the protein load required by the experiments. The final volume of the hydrolysis reaction was completed with $50 \mathrm{mM} \mathrm{pH} 5.0$ citrate buffer. The reaction was carried out at $50^{\circ} \mathrm{C}$ for 48 hours, and after that period, glucose determination in solution was performed by the glucose-oxidase method [24] [25] using the Enzyme Glucose Kit (In Vitro®).

\section{Formulation of enzyme cocktail for hydrolysis of biomass}

To obtain an ideal mixture from the concentrated enzymatic extracts of the fungi LMI01, LMI03 and T. reesei, experimental design of the simplex-centroid mixture was used, which generated a matrix with 10 experiments. The independent factors were the protein percentages of each concentrated 
enzyme extract, where the value of $15 \mathrm{mg}$ of protein/g of solid waste (cellulose pulp or cassava peel) was considered $100 \%$. The response variable was the glucose concentration $(\mathrm{g} / \mathrm{L})$ after $48 \mathrm{~h}$ of hydrolysis at $50^{\circ} \mathrm{C}$. The formulation of the cocktails was conducted using the values of total proteins $(\mathrm{mg} / \mathrm{mL})$ of each enzymatic extract to be added in the matrix experiments.

With the results obtained, statistical analysis was performed using the $95 \%$ confidence interval $(p \leq 0.05)$, to decide which model was adequate to explain the data, the following tools were used: analysis of variance with $F$ test $(p \leq$ 0.5 ), lack of fit and $R^{2}$. After the statistical analysis and the obtention of the model, the validation of the optimal mixture was performed with 3 experimental repetitions.

\section{Optimization of solid and protein loading}

The proportion of solid residue $(\mathrm{g} / \mathrm{L})$ and protein concentration $(\mathrm{mg} / \mathrm{g})$ for an efficient hydrolysis, was optimized through the Central Composite Rotational Design (CCRD), followed by validation. Table 1 shows the levels investigated. The experimental matrix was composed of 11 tests, with 3 repetitions at the central point. The enzymatic cocktails were incubated together with the solid residue (cellulose pulp or cassava peel) within the proportions indicated by the matrix. Glucose production $\mathrm{g} / \mathrm{L}$ and hydrolytic efficiency (HE\%) were considered the response variables.

Table 1 CCRD factors and levels for optimization of solid and protein loading

\begin{tabular}{lccccc}
\hline \multirow{2}{*}{ Factors } & \multicolumn{5}{c}{ Levels } \\
\cline { 2 - 6 } & -1.44 & -1 & 0 & +1 & +1.44 \\
\hline Solid concentration $(\mathrm{g} / \mathrm{L})$ & 6.75 & 25 & 52 & 89 & 97.25 \\
Protein $(\mathrm{mg} / \mathrm{g})$ & 9 & 15 & 30 & 45 & 51 \\
\hline
\end{tabular}

For the calculation of hydrolytic efficiency, the equation below was used, where: HE: Efficiency of enzymatic hydrolysis (\%); Solid waste $(\mathrm{g} / \mathrm{L})$ : concentration of solid waste used in hydrolysis; Cellulose $(\mathrm{g} / \mathrm{g})$ : cellulose concentration in the solids; 1.11: Conversion factor, related to the addition of a water molecule for the release of a glucose molecule, after the rupture of each covalent bond during hydrolysis.

$$
H E(\%)=\frac{\text { Glucose }(g / L)}{\text { Solid waste }(g / L) \times \text { Cellulose }(g / g) \times 1,11} \times 100
$$

\section{Enzymatic assays and total protein quantification}

The enzymatic activities of endoglucanase (CMCase), $\beta$-glucosidase and xylanase were determined using $2 \%$ carboxymethylcellulose, $2 \%$ cellobiose and $2 \%$ xylan birchwood as substrate, respectively, in $50 \mathrm{mM}$ citrate buffer, $\mathrm{pH}$ 5.0. The enzymatic assays were conducted according to the methodologies described by Ghose [24] and Eveleigh et al. [25]. Enzymatic activities were 
determined in IU (International Units), where one unit of activity corresponds to $1 \mu \mathrm{mol}$ of product released per minute. The total protein concentration was determined by the Bradford method [26].

\section{Results and discussion}

\section{Production of the enzymatic extracts, protein profile in SDS-Page and Zimogram}

The levels of enzymatic activities and total protein concentration observed in the extracts after $72 \mathrm{~h}$ of submerged fermentation, were different among Penicillium citrinum LMI01, Aspergillus sp LMI03 and T.reesei, as shown in Fig. 1 According to the enzymatic activity profiles of the P.citrinum LMIO1 and Aspergillus sp LMI03, the enzymatic preparations of these fungi can contribute to offer synegisms to enzymatic preparations of $T$. reesei, particularly with regard to beta-glucosidase activity, a key enzyme in glucose production [27] [17] . Likewise, the high levels of xylanases from these fungi can contribute strongly to synergisms for disruption of solid substrates rich in hemicellulose [27] [28]

Table 2 exhibits the levels of enzymatic activities and the concentration of total proteins $(\mathrm{mg} / \mathrm{mL})$ in the enzyme extracts crude, whose volumes were reduced 100 times. FPase activity was higher in the enzymatic extract of T.reesei (250 $\mathrm{U} / \mathrm{L}$ ), while LMI03 showed a higher level of $\beta$-glucosidase activity (2240 U/L) and considerable xylanase activity $(29020 \mathrm{U} / \mathrm{L})$, and the total protein content in the crude extract of $T$. reesei was also higher than that observed in strain LMI01 and LMI03, after $72 \mathrm{~h}$ of submerged fermentation. These enzymatic activities increased after extracts enzymatics volume concentration, $T$. reesei's fpase activity increased to 1,388.5 U/L, Aspergillus sp LMI03's $\beta$ glucosidase activity and xylanase activity rise for 105,447.2 U/L and 234,103.2 $\mathrm{U} / \mathrm{L}$, respectively. 


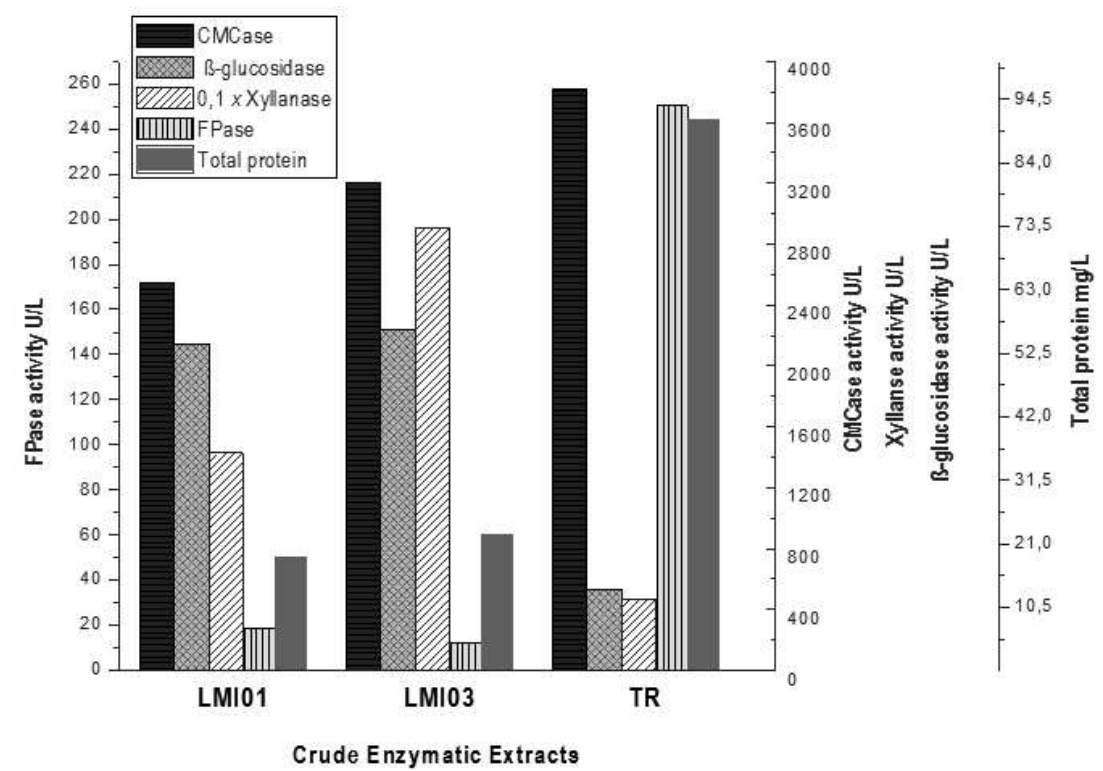

Fig. 1 Enzymatic activities and total protein concentration in crude enzymatic extracts, after 72 hours of submerged fermentation, with industrial cellulose pulp as a carbon source

Table 2 Enzymatic activities and total protein concentration in the concentrated extracts*

\begin{tabular}{lrrr}
\hline & P. citrinum LMI01 & Aspergillus sp. LMI03 & \multicolumn{1}{c}{ T.reesei } \\
\cline { 2 - 4 } FPase U/L & $216.3 \pm 0.3$ & $227.4 \pm 30.8$ & $1,388.5 \pm 18.8$ \\
CMCase U/L & $121,448.5 \pm 9323.6$ & $179,005.1 \pm 878.3$ & $457,057.2 \pm 6148.7$ \\
$\beta$-glucosidase U/L & $101,793.1 \pm 6630.5$ & $105,447.2 \pm 9,766.0$ & $13,050.4 \pm 904.2$ \\
Xylanase U/L & $105,720.4 \pm 1184.0$ & $234,103.2 \pm 5,800.8$ & $277,920.8 \pm 966.8$ \\
Total protein mg/L & $333.2 \pm 13.5$ & $1,045.1 \pm 20.2$ & $1,524.4 \pm 24.4$ \\
*Volume enzymatic extract crude concentrated up to 100 times by tangential filtration in 3kDa cutoff hollow-fiber \\
membrane
\end{tabular}

(Fig. 2a) shows the electrophoretic profile of the crude enzymatic extracts of the fungi platforms. In the extract of $P$. citrinum LMI01 it was observed the presence of 8 protein bands with an approximate molecular weight of: $20 \mathrm{kDa}$, $38 \mathrm{kDa}, 35 \mathrm{kDa}, 29 \mathrm{kDa}, 30 \mathrm{kDa}, 50 \mathrm{kDa}, 76 \mathrm{kDa}$ and $140 \mathrm{kDa}$. In the Aspergillus sp LMI03 extract, it was identified at least 16 defined bands with molecular weight of approximately: $13 \mathrm{kDa}, 15 \mathrm{kDa}, 17 \mathrm{kDa}, 19 \mathrm{kDa}, 22 \mathrm{kDa}$, $31 \mathrm{kDa}, 35 \mathrm{kDa}, 38 \mathrm{kDa}, 40 \mathrm{kDa}, 50 \mathrm{kDa}, 52 \mathrm{kDa}, 60 \mathrm{kDa}, 68 \mathrm{kDa}, 76 \mathrm{kDa}, 80 \mathrm{kDa}$ and $130 \mathrm{kDa}$. And, in the extract of $T$. reesei QM9414, 5 protein bands with high intensity were revealed, with molecular weight of approximately: $80 \mathrm{kDa}$, $52 \mathrm{kDa}, 40 \mathrm{kDa}, 35 \mathrm{kDa}$ and $19 \mathrm{kDa}$, and 5 bands with less intensity: $102 \mathrm{kDa}$, $30 \mathrm{kDa}, 28 \mathrm{kDa}, 24 \mathrm{kDa}$ and $26 \mathrm{kDa}$.

In the zymogram for endoglucanases (Fig. 2b), the crude extract of $T$. reesei QM9414 showed areas of CMC degradation at the height of protein bands with a molecular weight between $40 \mathrm{kDa}$ to $100 \mathrm{kDa}$, and three other bands of approximately: $35 \mathrm{kDa}, 30 \mathrm{kDa}$ and $19 \mathrm{kDa}$. Several studies have shown that Trichoderma genus are efficient in secreting cellulolytic enzymes [16] [29] [30]. A similar result to the obtained in this work was reported for $T$. harzianum, an effective strain species in degrading sugarcane bagasse cellulignin, which produces 6 different proteins with cellulosic activity with molecular weight of 
approximately: $48 \mathrm{kDa}, 55 \mathrm{kDa}, 59 \mathrm{kDa}, 62 \mathrm{kDa}, 69 \mathrm{kDa}$ and $78 \mathrm{kDa}$ [31], and for Trichoderma viride VKF3 which presented proteins with cellulolytic activities of molecular weight between 20.1-29.0 kDa and 14.3 KDa [32]. While other Trichoderma strains such as $T$. harzianum L04 showed two cellulolytic activities with distinct molecular weight (50 kDa and $20 \mathrm{kDa}$ ) [33], and two other strains of $T$. reesei and $T$. viride that presented proteins with cellulolytic activity of molecular weight between 23 - $42 \mathrm{KDa}$ [34].

$P$. citrinum LMI01 showed a CMC degradation region in the zymogram corresponding to proteins with an approximate molecular weight between 50 $\mathrm{kDa}$ to $100 \mathrm{kDa}$, and a halo of degradation in the height of proteins with molecular weight $\cong 35 \mathrm{kDa}$. Unlike what was observed for another species of the same genus, such as $P$. verruculosum BS3 isolated from the wood-yards on Kallai river belts, which in the zymogram showed a low molecular weight cellulase estimated at $17 \mathrm{kDa}$ [35]. Other species of Penicillium $s p$ have been described presenting proteins with cellulase activities close to those observed for $P$. citrinum LMI03, such as $P$. ochrochloron with a cellulase of $55 \mathrm{kDa}$ [36], $P$. echinulatum in which two bands of apparent molecular weight of approximately $80 \mathrm{kDa}$ and $250 \mathrm{kDa}$ were observed [37] and $P$. digitatum, which presented CMCase activity with an estimated molecular weight of $74 \mathrm{kDa}$ [38].

In Aspergillus sp LMI03 extract, it was observed an area of CMC degradation corresponding to proteins of approximately $52 \mathrm{kDa}, 80 \mathrm{kDa}$, and 2 bands with a degradation area at the height of $\cong 37 \mathrm{kDa}$ and $\cong 29 \mathrm{kDa}$. Other fungi of Aspergillus genus produce multiple cellulases with molecular weight similar to those found in this work, as observed in the zymogram of $A$. tubingensis, which presented protein bands with cellulose activity in the range of $30 \mathrm{kDa}-50 \mathrm{kDa}$ [39]. A. fumigatus Z5 zymogram analysis showed eight types of CMCase with molecular weight between $20 \mathrm{kDa}-50 \mathrm{kDa}$ secreted by this fungus [40], and $A$. fumigatus FBSPE-05 in which six bands of cellulase activity were observed with estimated molecular weight of $94.9,82.2,73.4,56.4,35.3$ and $27.3 \mathrm{kDa}$ [41]. While, some species are described producing only one type of cellulose (presenting only 1 protein band), as for example, A. glaucus, which presented a cellulolytic activity protein band with molecular weight $31 \mathrm{kDa}$ [42], A. niger IMMIS1 whose electrophoretic profile of its secreted proteins revealed a 71 KDa molecular weight cellulase [43]; Another strain, A. fumigatus ABK9 that presented a protein with cellulolytic activity of a size of $56.3 \mathrm{kDa}$ (Jana et al., 2013) and $A$. terreus with cellulase activity protein of $29.1 \mathrm{kDa}$ (Narra et al., 2014). 


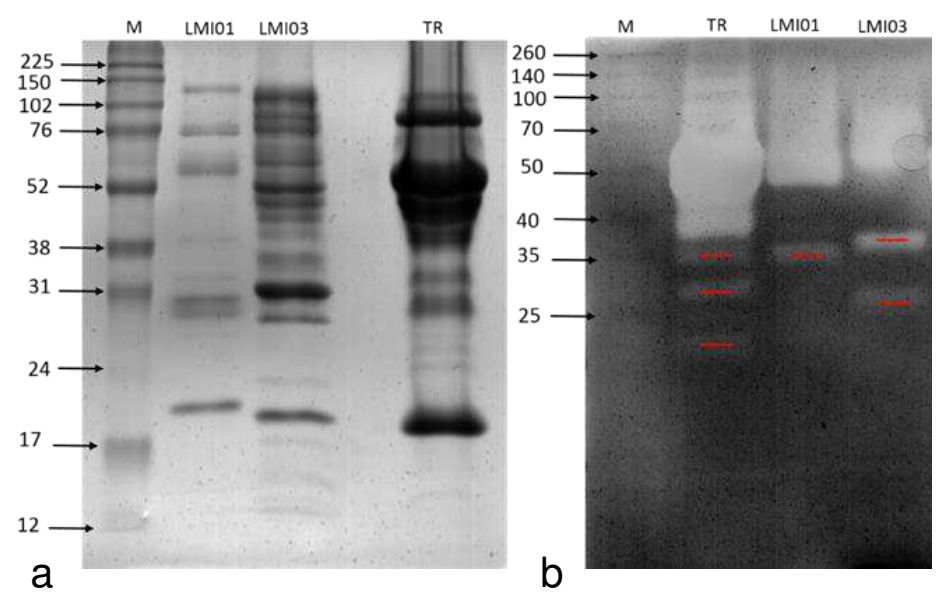

Fig. 2 Electrophoretic protein profile and zymogram for cellulases of the crude extract of fungi. a SDS-PAGE polyacrylamide gel stained with Coomassie blue R-250; M: Molecular weight marker (225kDa to 12kDa). LMI01: P. citrinum $(6 \mu \mathrm{g})$; LMI03: Aspergillus sp $(9 \mu \mathrm{g})$; TR: $T$. reesei QM9414 (13.6 $\mu \mathrm{g})$. b SDS-PAGE gel zymogram $(0.2 \% \mathrm{CMC})$ stained with $1 \%$ Congo red. M: molecular weight marker (260kDa to $10 \mathrm{kDa})$, samples with a concentration of $5 \mu \mathrm{g}$ of total proteins

According to these results, the proteins secreted by the fungi $P$. citrinum LMIO1, Aspergillus sp LMIO3 and T. reesei QM9414 are very representative of enzymes that degrade cellulose. In addition, it is observed that proteins with cellulolytic activity of different molecular weight occur among the extracts of these fungi. As for example, in the Aspergillus sp LMI03 extract there is a protein band with cellulolytic activity of $\cong 29 \mathrm{kDa}$, which was not seen in the crude extract of $T$. reesei or in the extract of $P$. citrinum LMI01. These conditions are quite interesting, since the synergistic action between different enzymes can be advantageous for increasing the catalytic efficiency in enzymatic hydrolysis of polysaccharides.

Besides, proteins from different fungal sources are described as responsible by increasing the performance of commercials enzyme cocktails [14]. For example, the saccharification level of pre-treated sugarcane bagasse, produced by commercial enzymatic cocktails, was increased by the addition of extracellular proteins from wood-decaying fungi, and this fact was attributed to different proteins identified in the extracellular extract of these fungi, mainly proteins belonging to the families $\mathrm{GH} 5$ and $\mathrm{GH} 45$-endoglucanases, $\mathrm{GH} 3$ betaglucosidases and GH10-xylanases [8].

\section{Composition of different lignocellulosic biomass used in the enzymatic hydrolysis}

Industrial cellulose pulp can be an excellent alternative carbon source for the production of enzymes by filamentous fungi that are capable of being induced to produce lignocellulolytic enzymes by the presence of this carbon source rich in polysaccharides. In addition, this biomass from the cellulose industry can also be used in process conceptions of biorefineries for the production of second generation ethanol and other molecules [44]. Cassava peel is a common agro-industrial solid residue in Brazil, which can be also used in the 
production of cellulosic ethanol, in addition of being a source with great potential for the production of sugar syrups to obtain other molecules of industrial interest, due to its high fiber content. Current studies have demonstrated the potential of this residual biomass for obtaining biofuels [45] [46]. Table 3 shows the percentage composition of main components present in the cellulose pulp and cassava peel, used for enzymatic hydrolysis in this work.

Table 3 Composition of lignocellulosic biomass used in the enzymatic hydrolysis

\begin{tabular}{cccccc}
\hline Biomass & $\begin{array}{c}\text { Cellulose } \\
\%\end{array}$ & $\begin{array}{c}\text { Hemicellulose } \\
\%\end{array}$ & $\begin{array}{c}\text { Lignin } \\
\%\end{array}$ & $\begin{array}{c}\text { Ashes } \\
\%\end{array}$ & $\begin{array}{c}\text { Others } \\
\%\end{array}$ \\
\hline Cellulose pulp & 83.3 & 7.7 & 1.8 & 3.2 & 4.0 \\
Cassava peel & 55.7 & 11.5 & 15.0 & 5.0 & 12.0 \\
\hline
\end{tabular}

\section{Experimental Design for optimizing the composition of enzyme cocktails}

The matrix of experiments and results obtained in the design of Simplexcentroid mixture for the hydrolysis of cellulose pulp and cassava peel are described in table 4 . The quadratic model provided a best fit to the data with a correlation coefficient $(R 2)=99 \%$, for hydrolysis of cellulose pulp. This formulation was called cocktail AMZ1, and the model of the ideal cocktail formulation is represented by the equation 1 . For the hydrolysis of cassava peel, the ideal mixture was called the AMZ2 cocktail. The quadratic model fitted best the experimental data, with $\mathrm{R} 2=88 \%$, and the equation 2 represent this model.

(1):

$$
\text { Glucose }(g / L)=0.72 A+1.9 B+7.9 C+6.2 A B+42.1 A C+54.4 B C+0.28 \varepsilon
$$

(2):

$$
\text { Glucose }(g / L)=10.5 \mathrm{~A}+13.1 \mathrm{~B}+9.7 \mathrm{C}+12.1 \mathrm{AB}+16.2 \mathrm{AC}+10.4 \mathrm{BC}+0.65 \varepsilon
$$

Where, A: P. citrinum LMI01; B: Aspergillus sp LMI03; C: T. reesei QM9414; $\varepsilon$ : Error

Table 4 Matrix of experiments simplex-centroid mixture design and results

\begin{tabular}{cccccc}
\hline & \multicolumn{2}{c}{ Percentage of enzymatic extract } & \multicolumn{2}{c}{ Glucose release $(\mathrm{g} / \mathrm{L})$} \\
\cline { 2 - 6 } Run & LMI01 & LMI03 & QM9414 & cellulose pulp & $\begin{array}{c}\text { cassava } \\
\text { peel }^{\mathrm{c}}\end{array}$ \\
\hline 1 & 1.00 & 0.00 & 0.00 & 0.93 & 9.97 \\
2 & 0.00 & 1.00 & 0.00 & 1.87 & 10.65 \\
3 & 0.00 & 0.00 & 1.00 & 8.13 & 7.85 \\
4 & 0.50 & 0.50 & 0.00 & 2.50 & 11.98 \\
5 & 0.50 & 0.00 & 0.50 & 15.31 & 12.36 \\
6 & 0.00 & 0.50 & 0.50 & 18.75 & 12.17
\end{tabular}




\begin{tabular}{cccccc}
7 & 0.33 & 0.33 & 0.33 & 15.00 & 11.60 \\
8 & 0.67 & 0.17 & 0.17 & 9.37 & 13.02 \\
9 & 0.17 & 0.67 & 0.17 & 11.87 & 13.02 \\
10 & 0.17 & 0.17 & 0.67 & 15.62 & 11.74 \\
11 & 1.00 & 0.00 & 0.00 & 0.62 & 7.42 \\
12 & 0.00 & 1.00 & 0.00 & 1.56 & 11.27 \\
13 & 0.00 & 0.00 & 1.00 & 8.12 & 7.47 \\
14 & 0.50 & 0.50 & 0.00 & 2.81 & 13.31 \\
15 & 0.50 & 0.00 & 0.50 & 14.68 & 11.27 \\
16 & 0.00 & 0.50 & 0.50 & 18.12 & 11.60 \\
17 & 0.33 & 0.33 & 0.33 & 15.03 & 12.69 \\
18 & 0.67 & 0.17 & 0.17 & 8.43 & 12.45 \\
19 & 0.17 & 0.67 & 0.17 & 10.62 & 12.45 \\
20 & 0.17 & 0.17 & 0.67 & 16.87 & \\
\hline
\end{tabular}

*a. Percentage of enzymatic extract used in hydrolysis, according with total proteins concentration (mg). ${ }^{\text {b; }}$ : Solid waste used in the proportion of $25 \mathrm{~g} / \mathrm{L}$

In tables 5 and 6 are shown the Mathematical models coefficients from DOE mix to hydrolysis of cellulose pulp and cassava peel, respectively. It is observed that for the release of glucose from the cellulose pulp, the enzymatic extract of $P$. citrinum LMI01 had no statistically significant effect $(p \geq 0.05)$, whereas, the enzymatic extracts of Aspergillus sp LMI03 and T. reesei QM9414 were statistically significant $(p<0.05)$. However, for the hydrolysis of cassava peel, the enzymatic extracts of the three fungi LMI03, LMI01 and T. reesei QM9414 were statistically significant $(p<0.05)$.

In triangular contour surfaces generated by the models (Fig. 3 ), it is possible to observe that, for the hydrolysis of the cellulose pulp, the cocktail formulation around $50 \%$ of enzymatic extract of Aspergillus sp LMI03 and $50 \%$ of T.reesei QM9414, in terms of $\mathrm{mg}$ of protein, provides an improvement in response. While, for cassava peel hydrolysis, as higher the relative proportion of the Aspergillus sp LMI03 enzymatic extract, the greater is the glucose release.

Table 5 Mathematical model coefficients from DOE mix to cellulose pulp hydrolysis

\begin{tabular}{lcccc}
\hline Factor & Coeff. & Std.Err. & $t$ & $p$ \\
\hline (A) P. citrinum LMI01 & 0.72 & 0.36 & 2.00 & 0.070 \\
(B) Aspergillus sp. LMI03 & 1.90 & 0.36 & 5.26 & $<0.05$ \\
(C) T.reesei QM9414 & 7.97 & 0.36 & 22.04 & $<0.05$ \\
AB & 6.21 & 1.67 & 3.73 & $<0.05$ \\
AC & 42.09 & 1.67 & 25.25 & $<0.05$ \\
BC & 54.45 & 1.67 & 32.67 & $<0.05$ \\
\hline \multicolumn{1}{c}{ p } & & & &
\end{tabular}

Table 6 Mathematical model coefficients from DOE mix to cassava peel hydrolysis

\begin{tabular}{lcccc}
\hline \multicolumn{1}{c}{ Factor } & Coeff. & Std.Err. & $t$ & $p$ \\
\hline (A) P. citrinum LMI01 & 8.88 & 0.57 & 15.70 & $<0.05$ \\
(B) Aspergillus sp. LMI03 & 10.93 & 0.57 & 19.33 & $<0.05$
\end{tabular}




\begin{tabular}{lcccc} 
(C) T.reesei QM9414 & 7.81 & 0.57 & 13.82 & $<0.05$ \\
AB & 10.72 & 2.61 & 4.11 & $<0.05$ \\
AC & 14.37 & 2.61 & 5.51 & $<0.05$ \\
BC & 9.71 & 2.61 & 3.72 & $<0.05$ \\
\hline
\end{tabular}

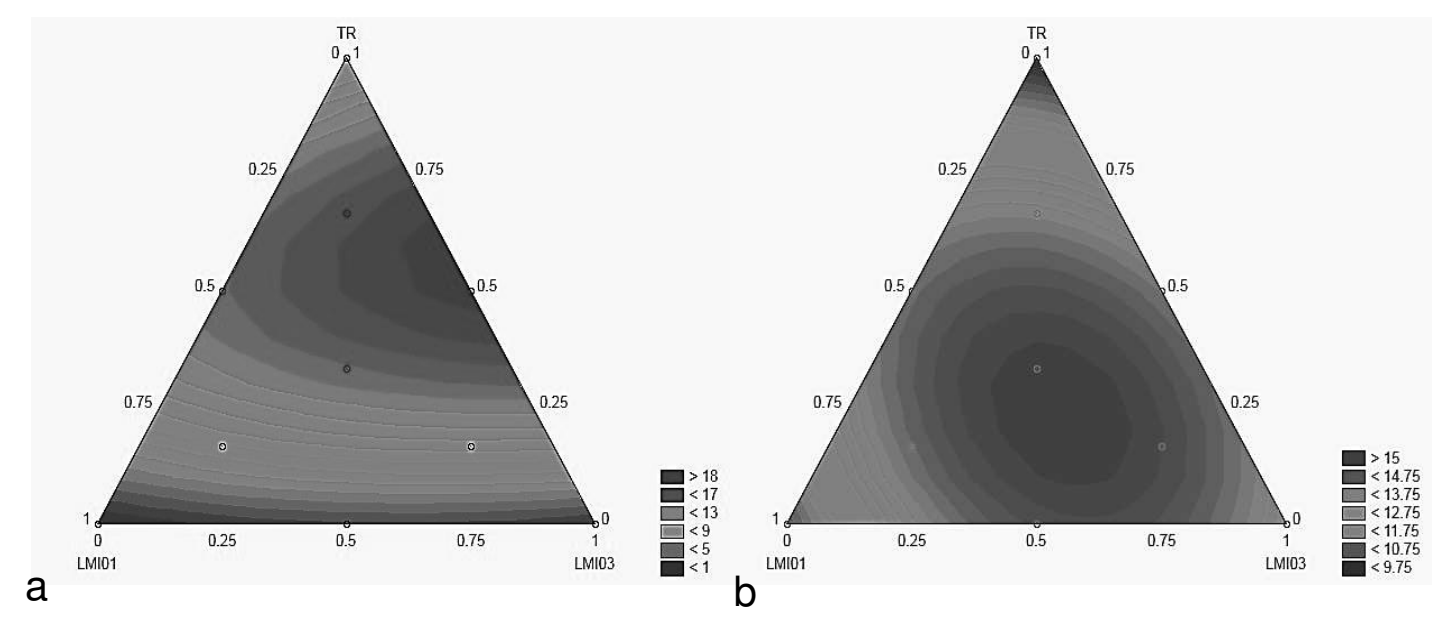

Fig. 3 Contour surfaces for quadratic models generated in the mix design. a AMZ1 cocktail for cellulose pulp hydrolysis; b AMZ2 cocktail for cassava peel hydrolysis

The validations of the optimized mixtures were made by the mathematical function Desirability, obtained in the software Statistica $\AA_{10.0}$. The Desirability value shows the percentage that the function meets the maximum that can be obtained in the answer. In table 7 shows the validation of the results and the ideal cocktail composition for cellulose pulp and cassava peel hydrolysis. The results experimentally obtained were close to those predicted by the function, indicating that the conditions predicted by the models and the Desirability function were validated.

Table 7 Validation of the optimized cocktails

\begin{tabular}{|c|c|c|c|c|c|c|}
\hline \multirow{2}{*}{ Cocktail } & \multirow{2}{*}{$\begin{array}{l}\text { Validation } \\
\text { condition }\end{array}$} & \multirow{2}{*}{$\begin{array}{c}\text { Desirability } \\
\text { value }\end{array}$} & \multicolumn{2}{|c|}{ Glucose $g / L$} & \multicolumn{2}{|c|}{ Confidence limits } \\
\hline & & & Observed & Predicted & $-95 . \%$ & $+95 \%$ \\
\hline AMZ 1 & 43\%LMI03+57\%TR & 0.96 & 19.1 & 18.7 & 18.0 & 19.4 \\
\hline AMZ 2 & $\begin{array}{c}50 \% \text { LMI03+ } \\
25 \% \text { LMI01+25\%TR }\end{array}$ & 0.97 & 12.7 & 13.1 & 12.5 & 13.7 \\
\hline
\end{tabular}

The individual enzymatic extracts of the fungi and the optimized cocktails AMZ 1 and AMZ 2 were evaluated in the hydrolysis of industrial cellulose pulp and cassava peel, using a protein loading of $15 \mathrm{mg} / \mathrm{g}$ and a solid loading $(25 \mathrm{~g} / \mathrm{L})$. In Fig. 4, the hydrolytic efficiency (\%) of the individual enzymatic fungal platforms 
and of the optimized cocktails are demonstrated, and it is possible to observe the superiority of the combined cocktails in relation to the individual enzymatic extracts. The individual enzymatic extracts of $P$. citrinum LMI01, Aspergillus sp LMI03 and T. reesei QM9414 presented hydrolysis efficiency of $4.0 \% ; 8.1 \%$ and $35.3 \%$ respectively, while hydrolytic efficiency AMZ1 cocktail was $82.9 \%$. For hydrolysis of the cassava peel, the AMZ2 cocktail showed $81.7 \%$ hydrolytic efficiency much higher than the individual enzymatic extracts $P$. citrinum, Aspergillus $s p$ and $T$. reesei, which values were as follows: $55.9 \%$; $68.5 \%$; $50.5 \%$, respectively.

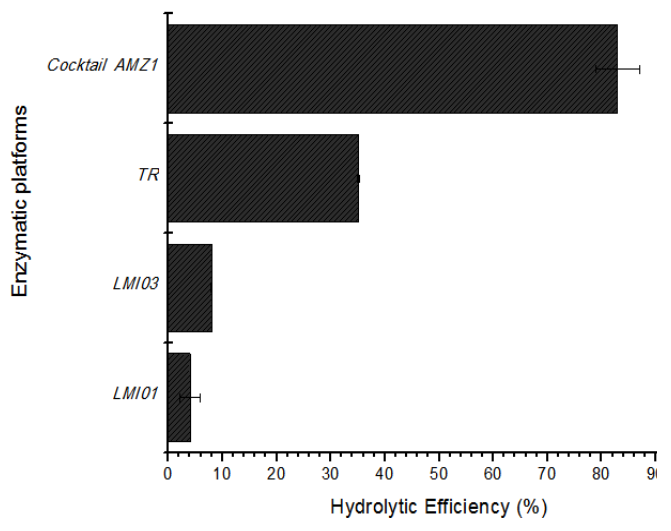

a

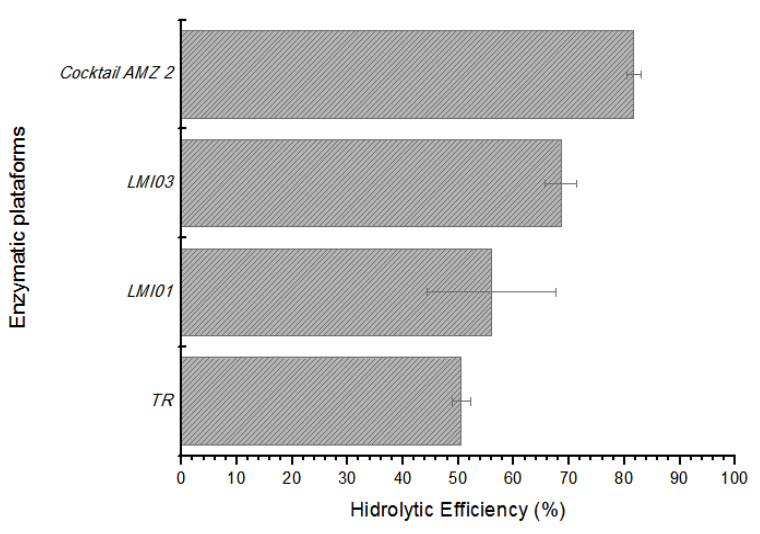

b

Fig. 4 Hydrolytic efficiency of the individual enzyme platforms and of the optimized cocktails, using $15 \mathrm{mg}$ of protein $/ \mathrm{g}$ of cellulose and $25 \mathrm{~g} / \mathrm{L}$ of solid residue. a hydrolysis of industrial cellulose pulp; $\mathbf{b}$ hydrolysis of cassava peel. LMI01: P. citrinum; LMI03: Aspergillus sp; TR: T. reesei QM9414; Cocktail AMZ1: 47\% LMI03 + 53\% TR; Cocktail AMZ2: 50\% LMI03 + 25\% TR + 25\% LMI01

The synergistic performance of the Aspergillus sp LMI03 enzymatic complex in combination with that of $T$. reesei QM9414 in cellulose pulp hydrolysis can be ascribed with the level of $\beta$-glucosidase production by LMI03, which is much higher than that of $T$. reesei QM9414, what contributed for an increase release of glucose and consequently led to an increase hydrolytic capacity of $T$. reesei enzymatic extract, since $\beta$-glucosidase prevents the inhibition of exoglucanases, by increasing the rate of cellobiose degradation that is known to be an strong inhibitor of these enzymes [17].

T. reesei QM9414 is known to produce high levels of cellullases, mainly endoglucanases and exoglucanases [47] [30], and this justifies the fact that its enzymatic extract was more efficient in the hydrolysis of cellulose pulp, considering that this biomass has a high content of available cellulose fibers, due to the process by which it is produced. In the process of producing cellulose pulp, the wood chips are subjected to several stages: cooking, purification and washing, delignification, washing again and storage, leaving this material partially delignified [48]. 
In contrast, the enzymatic extract of the fungi Aspergillus sp LMI03 was more influential in the cocktail during the hydrolysis of the cassava peel, although a percentage of $25 \% T$. reesei and $25 \%$ P. citrinum was required. This is quite interesting, since this biomass has a higher percentage of lignin and hemicellulose (12\% hemicellulose and $15 \%$ lignin) when compared to cellulose pulp ( $8 \%$ hemicellulose and $2 \%$ lignin). Thus, these results indicate that Aspergillus sp LMI03, most likely, have an efficient disruptive lignocellulolytic apparatus, making its enzymatic extract very interesting from the point of view of developing new cocktails for degradation of other lignocellulosic substrates with biotechnological potential [49].

This synergistic effect was similar to that observed in other works reported in literature. An enzymatic mixture prepared with commercial enzyme reinforced with enzymes of $P$. funiculosum and $T$. harzianum resulted in high sugar content released from the enzymatic hydrolysis of the pre-treated sugarcane bagasse [18]. Yet, in a blend prepared from enzymatic extracts of $P$. janthinellum, A. tubingenesis and T. reesei Rut C-30 resulted in an increase in Avicel hydrolysis [50]. In the hydrolysis of pre-treated sugar cane bagasse by an optimized mixture composed of $15 \% \mathrm{~T}$. harzianum, $50 \% \mathrm{P}$. funiculosum and $35 \%$ A. niger in protein basis, a hydrolysis yield of $91 \%$ was reached [51].

\section{Optimization of the solid waste and protein loading for biomass hydrolysis.}

In the process of biomass saccharification, the efficiency of hydrolysis is as important as the production of glucose itself, since high loads of enzymes entail a high cost in the process of deconstructing plant biomass aiming at the production of second generation ethanol and other chemicals [1][23]. Thus, the cocktails AMZ1 and AMZ2 were used to optimize the loading of solid waste $(\mathrm{g} / \mathrm{L})$ and protein $(\mathrm{mg} / \mathrm{g})$, in hydrolysis of industrial cellulose pulp and cassava peel, by means of CCRD. Aiming at to obtain an ideal proportion of developed cocktails, the effect of the different concentrations of solids and protein content required were evaluated, having as response the glucose release $(\mathrm{g} / \mathrm{L})$ and the hydrolysis efficiency (\%). The results obtained in the CCRD are shown in table 8. The highest values of glucose release were obtained at the midpoints of the experimental matrix, which for hydrolysis of the cellulose pulp it was around $45.7 \mathrm{~g} / \mathrm{L}$, and for hydrolysis of the cassava peel it was $29.4 \mathrm{~g} / \mathrm{L}$. Similarly, hydrolytic efficiency showed higher percentage values around the midpoint, in both solids used.

Table 8 CCRD results for optimization solid and protein loading

\begin{tabular}{|c|c|c|c|c|c|c|}
\hline \multirow{3}{*}{ Run } & \multirow{3}{*}{$\begin{array}{c}\text { Solid load a } \\
\text { g/L }\end{array}$} & \multirow{3}{*}{$\begin{array}{l}\text { Protein load } \\
\text { mg/g }\end{array}$} & \multicolumn{4}{|c|}{ Enzymatic cocktail } \\
\hline & & & \multicolumn{2}{|c|}{ AMZ1 } & \multicolumn{2}{|c|}{ AMZ2 } \\
\hline & & & Glucose g/L & $\mathrm{HE} \%$ & Glucose $\mathrm{g} / \mathrm{L}$ & $\mathrm{HE} \%$ \\
\hline 1 & 25 & 15 & 3.1 & 13.4 & 11.4 & 73.2 \\
\hline 2 & 25 & 45 & 9.1 & 39.5 & 12.3 & 79.0 \\
\hline 3 & 89 & 15 & 41.1 & 50.1 & 44.1 & 79.7 \\
\hline 4 & 89 & 45 & 26.6 & 32.4 & 27.0 & 48.9 \\
\hline 5 & 7 & 30 & 1.9 & 30.0 & 0.8 & 20.5 \\
\hline
\end{tabular}




\begin{tabular}{llccccc}
6 & 97 & 30 & 36.1 & 40.3 & 34.7 & 57.5 \\
7 & 52 & 9 & 24.6 & 51.3 & 20.2 & 62.5 \\
8 & 52 & 51 & 18.6 & 38.8 & 20.2 & 62.5 \\
$9(\mathrm{C})$ & 52 & 30 & 47.1 & 98.3 & 27.4 & 84.8 \\
$10(\mathrm{C})$ & 52 & 30 & 45.6 & 95.2 & 30.5 & 94.5 \\
$11(\mathrm{C})$ & 52 & 30 & 44.6 & 93.0 & 30.1 & 93.3 \\
\hline
\end{tabular}

a Solid residues used in hydrolysis with AMZ1 and AMZ2 cocktails: Industrial cellulose pulp and cassava peel respectively. Results obtained after $48 \mathrm{~h}$ of hydrolysis at $50^{\circ} \mathrm{C}$

The CCRD analysis of variance to AMZ1 cocktail showed that the model was adequate to explain the data, providing high values of the parameter $\mathrm{R}$ for glucose $\mathrm{g} / \mathrm{L}\left(R^{2}=98 \%\right)$ and for hydrolytic efficiency $\left(R^{2}=97 \%\right)$, and in addition, the lack of fit was not significant $(p>0.05)$ for both responses. As seen in the response surfaces (Fig. 6), the solid and protein loads around the average level studied $(52 \mathrm{~g} / \mathrm{L}$ of solid waste and $30 \mathrm{mg}$ of protein $/ \mathrm{g}$ ) allowed for higher glucose production and maximum hydrolytic efficiency. The following equations describe the model as a function of solid/protein loading, using the AMZ 1 cocktail, where: S: solid loading; P: protein loading, $\varepsilon$ : pure error.

Equation 3:

Glucose $g / L=45.76+12.97 S-13.45 S^{2}-2.12 P-12.16 P^{2}-5.12 S P+1.56 \varepsilon$

Equation 4:

Hydrolytic efficiency $\%=95.52+5.51 S-31.74 S^{2}-1.16 P-26.78 P^{2}-10.93 S P+6.89 \varepsilon$

The analysis of variance of the CCRD to optimize the solid and protein loadings using the AMZ2 cocktail, the explained variation percentages (R2) were $94 \%$ for glucose $\mathrm{g} / \mathrm{L}$ production and $70 \%$ for hydrolytic efficiency, and for both, the lack adjustment was not significant $(p>0.05)$. Analyzing the response surfaces for glucose production, it is observed that the increase in the loading of solids caused an improvement in the response, whereas the hydrolytic efficiency (\%) was higher in the central points (Fig. $5 \mathrm{c}$ and $5 \mathrm{~d}$ ).

To obtain an ideal proportion of the loading solid and protein in the cocktails, that would allow an optimal response for the production of glucose $\mathrm{g} / \mathrm{L}$ and for hydrolytic efficiency, the validation of the models obtained in the CCRD, was done by the Desirability function (value $=0.91$ ). According to the mathematical model of this function (Desirability value $=0.79$ ) for an optimal AMZ1 cocktail performance in the hydrolysis of cellulose pulp, $52 \mathrm{~g} / \mathrm{L}$ of solids should be used in combination with $30 \mathrm{mg}$ of protein in cocktail per $g$ of solids. Yet for the AMZ2 cocktail, the solid and protein loadings should be $78 \mathrm{~g} / \mathrm{L}$ and $19 \mathrm{mg}$ of protein per/g of waste. The results obtained in the validation after 48 hours of hydrolysis were satisfactory, within the established confidence limits (95\%).

In order to compare the performance of the cocktails developed in this work, with commercially available formulations, the commercial enzymes Multifect ${ }^{\circledR}$ and Cellic®CTec2 were incubated for hydrolysis of cellulose pulp and cassava peel, under the same conditions as AMZ1 and AMZ2. In cellulose pulp 
hydrolysis, it was found that the AMZ1 cocktail had higher levels of glucose production $(\mathrm{g} / \mathrm{L})$ and hydrolytic efficiency $(\%)$, than that observed for the commercial blend Multifect@, and presented a performance similar to that obtained with Cellic $\circledast$ CTec2 (Fig. 6). While in the hydrolysis of cassava peel, the cocktail AMZ 2, presented a slightly higher performance (38 g/L glucose and $78 \% \mathrm{HE})$ than that obtained with Multifect $(34 \mathrm{~g} / \mathrm{L}$ glucose; $70 \% \mathrm{HE})$. Similar results to these were obtained by Agrawal et al. [52], who reported a value of $75 \%$ for the enzymatic hydrolysis, using an enzyme mix developed with Trichoderma enzymes, and critical levels of $\beta$-glucosidase and xylanase, compared to individual commercial preparations, in the hydrolysis of pretreated wheat straw by steam explosion.

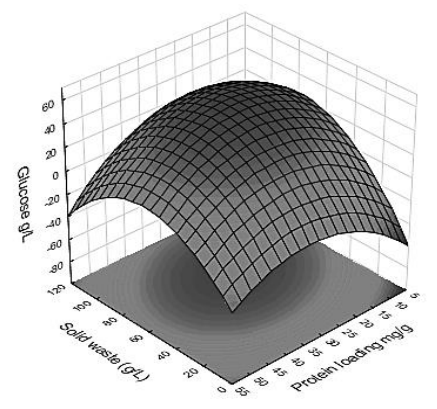

a

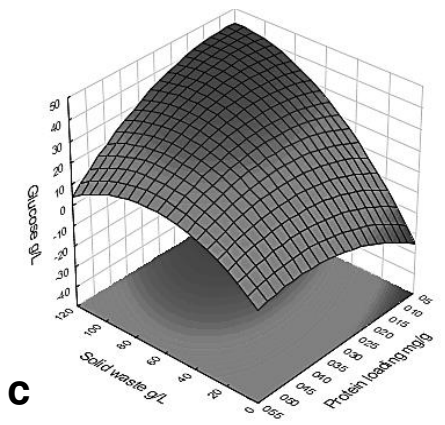

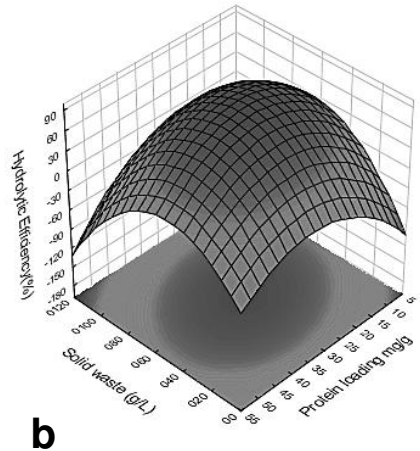

b

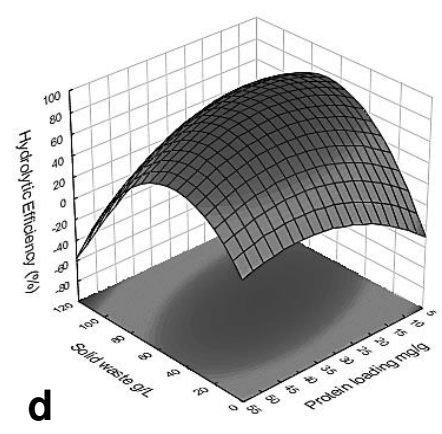

Fig. 5 Response surfaces for glucose released and hydrolytic efficiency as a function of loading solid and protein. a glucose $(\mathrm{g} / \mathrm{L})$, b Hydrolytic efficiency (\%) to AMZ1 cocktail. c and $\mathbf{d}$ glucose $(\mathrm{g} / \mathrm{L})$ and hydrolytic efficiency $(\%)$, to AMZ2 cocktail

Efficiency is linked not only to the enzymatic cocktail's ability to convert cellulose and hemicellulose into fermentable sugar monomers, but to how much of this material a low protein loading of enzymes can hydrolyze [1][53]. Accordingly, modern biorefinery require high efficiency enzyme cocktails for the generation of fermentable sugars from lignocellulosic biomass. In this sense, fungi are the microorganisms that have shown the greatest potential in terms of enzyme productivity and efficiency in enzyme production [14][29].

In addition, recent research has shown high levels of saccharification of lignocellulosic biomass and hydrolytic efficiency using enzymatic cocktails produced by filamentous fungi that contain proteins with auxiliary activities of cellulases, in the same way, extracellular proteins produced by fungi from 
rotting wood when added to commercial enzymatic preparations, enhanced their catalytic power [8][13]. Furthermore, Zerva et al [28] established the synergistic action between an active LPMO in xylan and a new fungal xylanase on cellulosic substrates, and observed a strong synergistic interaction in the degradation of the recalcitrant part of xylan, and also found that LPMO increased the cellobiose release by cellobiohydrolases during the hydrolysis of pretreated lignocellulosic substrates and microcrystalline cellulose.
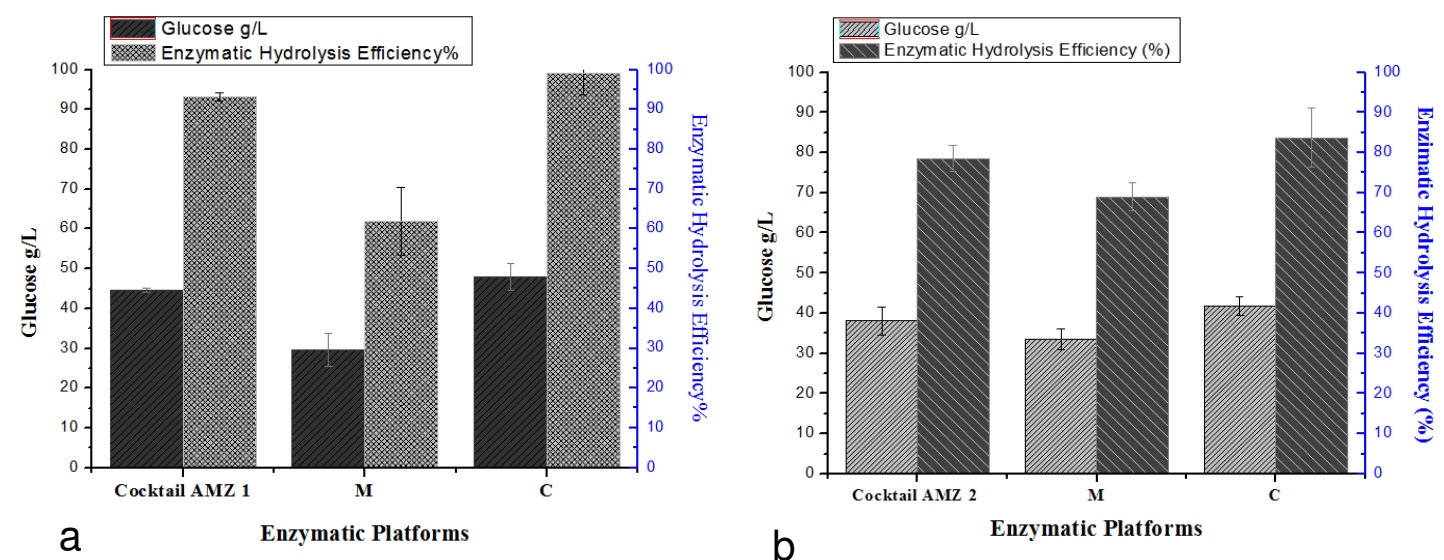

Fig. 6 Glucose released ( $\mathrm{g} / \mathrm{L}$ ) and hydrolytic efficiency (\%) after 48 h of hydrolysis at $50^{\circ} \mathrm{C}$. a hydrolysis of industrial cellulose pulp $(52 \mathrm{~g} / \mathrm{L})$ with $30 \mathrm{mg}$ of protein. $\mathbf{b}$ hydrolysis of cassava peel $(78 \mathrm{~g} / \mathrm{L})$ with $19 \mathrm{mg}$ of protein. M and C: commercial enzyme Multifect $\Theta$ and Cellic $\AA C T e c 2$ respectively

The increase in hydrolytic efficiency when combining extracellular proteins from the three different fungal platforms used in this work corroborate with the results observed in other works, in which higher levels of hydrolysis efficiency were obtained in balanced mixtures with different protein apparatus [18][50] [51][52]. According to this findings and compared with the results of the current literature, in fact it is evident that the efficiency of hydrolysis obtained in formulations with different fungi is of great impact when compared to the performance of enzymatic complexes obtained from only one species of fungi.

And, to strengthen this issue, other studies have confirmed that cellulolytic fungi such as $A$. niger and $T$. reesei RUT-C30 present a difference in genes related to the decomposition content of lignocellulose and also in its expression profile [15]. However, it is necessary to increase knowledge about the interactions between these proteins and between their substrates in terms of the complexity of the recalcitrant lignocellulosic matter. Once mixing enzymes from different sources is a sustainable approach that can increase the hydrolysis performance of cellulose, reducing the enzymatic deconstruction costs of lignocellulosic biomass [50][49]..

\section{Conclusions}

Extracellular proteins from Penicillium citrinum LMI01 and Aspergillus sp LMI03 isolated from the Amazon biome, showed high levels of xylanase and 
beta-glucosidase activity. In addition, the extracellular protein complexes of these fungi are able to act synergistically with the proteins secreted by the cellulolytic T. reesei QM9414, strain equivalent to QM 9414, which is of great importance, since the QM9414 strain is still one of the main bases of enzymatic formulations for hydrolysis of lignocellulosic biomass, due to its protein apparatus rich in endoglucanases, exoglucnases and carbohydrate binding modules (CBMs). The optimization of the ideal mixture for hydrolysis of cellulose pulp and cassava peel showed that the LMI03 protein complex was the most required to achieve a higher performance of hydrolytic efficiency, being required in critical values such as $47 \%$ and $53 \%$ of Aspergillus sp LMI03 in its protein composition. This fact shows the disruptive catalytic power of the enzymatic extract produced by this strain.

The results reported herein also show that the enzymatic cocktails formulated with the enzymatic apparatus produced by the fungi Aspergillus sp LMI03 and $P$. citrinum LMI01 are able to perform as well as commercial cocktails of high performance, and with satisfactory hydrolytic efficiency, since resulting in an hydrolysis efficiency above $80 \%$ in the hydrolysis of cellulose pulp (cocktail AMZ1) and cassava peel (cocktail AMZ2). In this way, the enzymatic cocktails obtained in this work present an efficient alternative for hydrolysis of pretreated or untreated vegetable biomass. In addition to providing investigative bases for future performance evaluations of these preparations in the deconstruction of other lignocellulosic biomass.

\section{References}

1. Pereira Jr, N., Couto, M. A. P. G., \& Santa Anna, L. M. M. (2008). Biomass of lignocellulosic composition for fuel ethanol production within the context of biorefinery. Series on Biotechnology, 2, 1-47.

2. Adsul, M., Sandhu, S. K., Singhania, R. R., Gupta, R., Puri, S. K., \& Mathur, A. (2020). Designing a cellulolytic enzyme cocktail for the efficient and economical conversion of lignocellulosic biomass to biofuels. Enzyme and Microbial Technology, 133, 109442.

3. Mandels, M., \& Reese, E. (1956). Induction of cellulase in trichoderma viride as influenced by carbon sources and metals. Journal of Bacteriology, 73(2): 269-278.

4. Bischof, R. H., Ramoni, J., \& Seiboth, B. (2016). Cellulases and beyond: the first 70 years of the enzyme producer Trichoderma reesei. Microbial Cell Factories, 15(1), 106.

5. Dashtban, M., Buchkowski, R., \& Qin, W. (2011). Effect of different carbon sources on cellulase production by Hypocrea jecorina (Trichoderma reesei) strains. International journal of biochemistry and molecular biology, 2(3), 274-86.

6. Zabed, H., Sahu, J. N., Boyce, A. N., \& Faruq, G. (2016). Fuel ethanol production from lignocellulosic biomass: An overview on feedstocks and technological approaches. Renewable and Sustainable Energy Reviews, 66, 751-774.

7. Sun, F. F., Hong, J., Hu, J., Saddler, J. N., Fang, X., Zhang, Z., \& Shen, S. (2015). Accessory enzymes influence cellulase hydrolysis of the model substrate and the realistic lignocellulosic biomass. Enzyme and Microbial Technology, (79-80), 42-48.

8. Valadares, F., Gonçalves, T. A., Gonçalves, D. S. P. O., Segato, F., Romanel, E., Milagres, A. M. F., Ferraz, A. (2016). Exploring glycoside hydrolases and accessory proteins from wood decay fungi to enhance sugarcane bagasse saccharification. Biotechnology for Biofuels, 9(1), 110.

9. Levasseur, A., Drula, E., Lombard, V., Coutinho, P. M., \& Henrissat, B. (2013). Expansion of the enzymatic repertoire of the CAZy database to integrate auxiliary redox enzymes. 
Biotechnology for biofuels, 6(1), 41.

10.Eijsink, V. G. H., Ludwicka, K., Felice, A. K. G., Preims, M., Ludwig, R., Breslmayr, E., Scheiblbrandner, S. (2016). Extracellular electron transfer systems fuel cellulose oxidative degradation. Science, 352(6289), 1098-1101.

11.Saloheimo, M., Paloheimo, M., Hakola, S., Pere, J., Swanson, B., \& Nyysso, E. (2002). Swollenin, a Trichoderma reeseiprotein with sequence similarity to the plant expansins, exhibits disruption activity on cellulosic materials. European journal of biochemistry, 269, 4202-4211.

12. Obeng, E. M., Adam, S. N. N., Budiman, C., Ongkudon, C. M., Maas, R., \& Jose, J. (2017). Lignocellulases: a review of emerging and developing enzymes, systems, and practices. Bioresources and Bioprocessing, 4(1).

13. Cesar, F., Maria, B., Silvello, A., \& Goldbeck, R. (2020). Cellulase and oxidative enzymes: new approaches, challenges and perspectives on cellulose degradation for bioethanol production. Biotechnology Letters, 42(6), 875-884.

14. Mohanram, S., Amat, D., Choudhary, J., Arora, A., \& Nain, L. (2013). Novel perspectives for evolving enzyme cocktails for lignocellulose hydrolysis in biorefineries. Sustainable Chemical Processes, 1(1), 15.

15. Borin, G. P., Sanchez, C. C., de Santana, E. S., Zanini, G. K., dos Santos, R. A. C., Oliveira Pontes, A., Souza .T.A., Dal'Mas, R.M.M.T. S., Riaño-Pachón, D. M., Goldman, G.H., Oliveira, J.V.C. (2017). Comparative transcriptome analysis reveals different strategies for degradation of steam-exploded sugarcane bagasse by Aspergillus niger and Trichoderma reesei. BMC Genomics, 18:501.

16. Seiboth, B., Ivanova, C., Seidl-Seiboth, V. (2011). Trichoderma reesei: A Fungal Enzyme Producer for Cellulosic Biofuels, Biofuel Production-Recent Developments and Prospects, Dr. Marco Aurelio Dos Santos Bernardes (Ed.), ISBN: 978-953-307-478-8, InTech, Available from: http://www.intechopen.com/books. Accessed December 15, 2020.

17. Singhania, R. R., Patel, A. K., Sukumaran, R. K., Larroche, C., \& Pandey, A. (2013). Role and significance of beta-glucosidases in the hydrolysis of cellulose for bioethanol production. Bioresource technology, 127, 500-7.

18. Maeda, N. R., Isabel, V., Alves, V., Rocha, L., Aparecida, R., Mesquita, A., São-carlense, A. T. (2011). Enzymatic hydrolysis of pretreated sugar cane bagasse using Penicillium funiculosum and Trichoderma harzianum cellulases. Process Biochemistry, 46(5), 11961201.

19. Santa-Rosa, P. S., Souza, A. L., Roque, R. A., Andrade, E. V., Astolfi-Filho, S., Mota, A. J., \& Nunes-Silva, C. G. (2018). Production of thermostable $\beta$-glucosidase and CMCase by Penicillium sp. LMI01 isolated from the Amazon region. Electronic Journal of Biotechnology, 31, 84-92.

20. Mandels, M., \& Weber, J. (1969). The production of cellulases. Advances in Chemistry, 95, 391-414.

21. Laemmli, R. (1996). Mini-PROTEAN TGX TM Gel: A Versatile and Robust Laemmli-Like Precast Gel for SDS-PAGE, 5-8.

22. Schwarz, W. H., Bronnenmeier, K., \& Staudenbauer, W. L. (1987). Activity Staining of Cellulases in Polyacrylamide Containing Mixed Linkage P-Glucans Gels, 77, 72-77.

23.Barcelos, C. A., Maeda, R. N., Betancur, G. J. V., \& Pereira, N. (2013). The Essentialness of Delignification on Enzymatic Hydrolysis of Sugar Cane Bagasse Cellulignin for Second Generation Ethanol Production. Waste and Biomass Valorization, 4(2), 341-346.

24. Ghose, T. K. (1987). Measurement of Cellulase Activities. Pure \& Appl. Chem., 59(2), 257268.

25. Eveleigh, D. E., Mandels, M., Andreotti, R., \& Roche, C. (2009). Measurement of saccharifying cellulase. Biotechnology for Biofuels, 2(1), 21.

26. Bradford, M. M. (1976). A rapid and sensitive method for the quantitation of microgram quantities of protein utilizing the principle of protein-dye binding. Analytical Biochemistry, 72(1-2), 248-254.

27. Li, J., Zhou, P., Liu, H., Xiong, C., Lin, J., Xiao, W., ... Liu, Z. (2014). Synergism of cellulase, xylanase, and pectinase on hydrolyzing sugarcane bagasse resulting from different pretreatment technologies. Bioresource Technology.

28. Zerva, A., Pentari, C., Grisel, S., Berrin, J. G., \& Topakas, E. (2020). Biotechnology for Biofuels A new synergistic relationship between xylan - active LPMO and xylobiohydrolase to tackle recalcitrant xylan. Biotechnology for Biofuels, 1-13. 
29. Reyes-Sosa, F. M., López Morales, M., Platero Gómez, A. I., Valbuena Crespo, N., Sánchez Zamorano, L., Rocha-Martín, J., ... Díez García, B. (2017). Management of enzyme diversity in high-performance cellulolytic cocktails. Biotechnology for Biofuels, 10(1), 1-10.

30. Cologna, N. de M. di, Gómez-Mendoza, D. P., Zanoelo, F. F., Giannesi, G. C., Guimarães, N. C. de A., Moreira, L. R. de S., Ricart, C. A. O. (2018). Exploring Trichoderma and Aspergillus secretomes: Proteomics approaches for the identification of enzymes of biotechnological interest. Enzyme and Microbial Technology, 109, 1-10.

31. Rocha, V. A. L., Maeda, R. N., Santa Anna, L. M. M., \& Pereira Jr., N. (2013). Sugarcane bagasse as feedstock for cellulase production by Trichoderma harzianum in optimized culture medium. Journal of BElehnologyctroniciotec, 16(5), 1-13.

32. Nathan, V., Esther Rani, M., Rathinasamy, G., Dhiraviam, K., \& Jayavel, S. (2014). Process optimization and production kinetics for cellulase production by Trichoderma viride VKF3. SpringerPlus, 3(1), 92.

33. Benoliel, B., Torres, F. A. G., \& de Moraes, L. M. P. (2013). A novel promising Trichoderma harzianum strain for the production of a cellulolytic complex using sugarcane bagasse in natura. SpringerPlus, 2, 656.

34. Pirzadah, T., Garg, S., Singh, J., Vyas, A., Kumar, M., Gaur, N., \& Bala, M. (2014). Characterization of Actinomycetes and Trichoderma spp . for cellulase production utilizing crude substrates by response surface methodology. SpringerPlus, 3(1), 1-12.

35. Sajith, S., Sreedevi, S., Priji, P., Unni, K. N., \& Benjamin, S. (2015). Production and Partial Purification of Cellulase from a New Isolate, Penicillium verruculosum BS3. British Microbiology Research Journal, 9(1), 1-12.

36. Parambath, J. N., Valsala, G., \& Krishnan, S. R. (2016). Purification and characterization of carboxymethyl cellulase (cmcase) from Penicillium ochrochloron isolated from forest soil of Neyyar Wild Life Sanctuary, India. International Journal of Biotechnology and Biochemistry, 12(2), 131-144.

37. Eliana, C., Ritter, T., Camassola, M., Zampieri, D., Silveira, M. M., José, A., \& Dillon, P. (2013). Cellulase and Xylanase Production by Penicillium echinulatum in Submerged Media Containing Cellulose Amended with Sorbitol, Enzyme Research, V. 2013, 240219, 9.

38. Santos, F. C. dos, Oliveira, M. A. S. de, Seixas, F. A. V., \& Barbosa-Tessmann, I. P. (2020). A Novel Cellobiohydrolase I ( CBHI ) from Penicillium digitatum: Production, Purification, and Characterization. Applied Biochemistry and Biotechnology ,192, 257282.

39. Prajapati, B. P., Kumar Suryawanshi, R., Agrawal, S., Ghosh, M., \& Kango, N. (2018). Characterization of cellulase from Aspergillus tubingensis NKBP-55 for generation of fermentable sugars from agricultural residues. Bioresource Technology, 250, 733-740.

40. Liu, D., Zhang, R., Yang, X., Zhang, Z., Song, S., Miao, Y., \& Shen, Q. (2012). Characterization of a thermostable b -glucosidase from Aspergillus fumigatus $Z 5$, and its functional expression in Pichia pastoris X33. Microbial Cell Factories, 11(1), 25.

41. Souza, D. T., Bispo, A. S. R., Bon, E. P. S., Coelho, R. R. R., \& Nascimento, R. P. (2009). Aspergillus fumigatus Thermophilic and Acidophilic Endoglucanases, 321-329.

42. Tao, Y. M., Zhu, X. Z., Huang, J. Z., Ma, S. J., Wu, X. B., Long, M. N., \& Chen, Q. X. (2010). Purification and properties of endoglucanase from a sugar cane bagasse hydrolyzing strain, aspergillus glaucus XC9. Journal of Agricultural and Food Chemistry, 58(10), 6126-6130.

43. Imran, M., Sciences, A., \& Anwar, Z. (2018). Production and characterization of commercial cellulase produced through aspergillus niger IMMIS1 after screening fungal species. Pakistan Journal of Botany, 50(4): 1563-1570.

44. Moraes, A. D. O., Modesto, L. F., Isabel, N., Ramirez, B., \& Jr, N. P. (2016). Reuse of Residual Biomass of Cellulose Industry for Second Generation Bioethanol Production. Journal of advances in biotechnology, 6(1), 768-772.

45. Bayitse, R., Hou, X., Bjerre, A.-B., \& Saalia, F. K. (2015). Optimisation of enzymatic hydrolysis of cassava peel to produce fermentable sugars. AMB Express, 5(1), 60.

46. Efeovbokhan, V. E., Egwari, L., Alagbe, E. E., Adeyemi, J. T., \& Taiwo, O. S. (2019). Production of Bioethanol from Hybrid Cassava Pulp and Peel using Microbial and Acid Hydrolysis. BioResources, 14(2), 2596-2609.

47. Jun, H., Kieselbach, T., \& Jönsson, L. J. (2011). Enzyme production by filamentous fungi: analysis of the secretome of Trichoderma reesei grown on unconventional carbon source. 
Microbial Cell Factories, 10:68.

48. Chen, C., Duan, C., Li, J., Liu, Y., \& Ma, X. (2016). Cellulose (Dissolving Pulp) Manufacturing Processes and Properties: A Mini-Review, BioResources 11(2), 5553-5564.

49. Lopes, A. M., Filho, E. X. F., \& Moreira, L. R. S. (2018). An update on enzymatic cocktails for lignocellulose breakdown. Journal of Applied Microbiology, 125, 632--645.

50. Adsul, M., Sharma, B., Singhania, R. R., Saini, J. K., Sharma, A., Mathur, A., Tuli, D. K. (2014). Blending of cellulolytic enzyme preparations from different fungal sources for improved cellulose hydrolysis by increasing synergism. RSC Advances, 4(84), 4472644732.

51. Arias, J. M., Modesto, L.F.A., Polikarpov, I., Pereira-Jr, N. (2016). Design of an Enzyme Cocktail Consisting of Different Fungal Platforms for Efficient Hydrolysis of Sugarcane Bagasse: Optimization and Synergism Studies. Biotechnology Progress, (00), 1-8.

52. Agrawal, R., Semwal, S., Kumar, R., Mathur, A., \& Gupta, R. P. (2018). Synergistic Enzyme Cocktail to Enhance Hydrolysis of Steam Exploded Wheat Straw at Pilot Scale. Frontiers in Energy Research, 6:122, 1-11.

53. Teter, S., Sutton, B., Emme, B. (2014). Enzymatic processes and enzyme development in biorefning. Advances in Biorefineries: Biomass and Waste Supply Chain Exploitation, 02, 199-233. 


\section{Declarations}

\section{Funding}

The authors wish to express their gratitude for the financial support from National Council for Scientific and Technological Development (CNPq), Research Support in the State of Amazonas (FAPEAM) and Coordination for the Improvement of Higher Education Personnel (CAPES).

\section{Conflicts of interest/Competing interests}

We wish to confirm that there are no known conflicts of interest associated with this publication. We confirm that all of us have approved the order of authors listed in the manuscript, and we confirm further that there are no other persons who satisfied the criteria for authorship but are not listed.

We understand that the Corresponding Author is the sole contact for the Editorial process (including Editorial Manager and direct communications with the office). $\mathrm{He}$ is responsible for communicating with the other authors about progress, submissions of revisions and final approval of proofs. We confirm that we have provided a current, correct email address which is accessible by the Corresponding Author and which has been configured to accept email from pamellasuely@gmail.com

\section{Availability of data and material}

All datasets presented in this study are included in the article/Supplementary Material

\section{Code availability}

Not applicable

\section{Authors' contributions}

PSSR, NPJ, and SAF conceived the study. PSSR and NPJ planned the experiments. PSSR and JBO carried out the experiments. PSSR, NPJ, and SAF contributed to the interpretation of the results. NPJ and SAF supervised the work. PSSR wrote the manuscript and NPJ and SAF contributed to the text and revised it. All authors read and approved the final version of the manuscript

\section{Ethics approval}

The activity of access to Genetic patrimony was registered in SisGen (National System of Management of Genetic Patrimony and Associated Traditional Knowledge) with the number A63F955, in compliance with the provisions of Law No. 13,123 / 2015 and its regulations of the Ministry of the Environment - Brazil.

\section{Consent to participate}


Not applicable

\section{Consent for publication}

Not applicable

we confirm that the manuscript has been read and approved by all named authors Signed by all authors as follows:

Pamelle Suely Santa Roso

- Pamella S. Santa-Rosa

Jessica Batista de Oliveira

- Jessica Batista de Oliveira

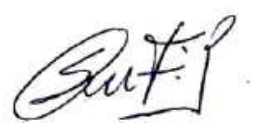

- Spartaco Astolfi-Filho

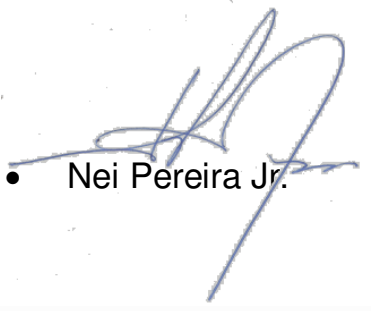




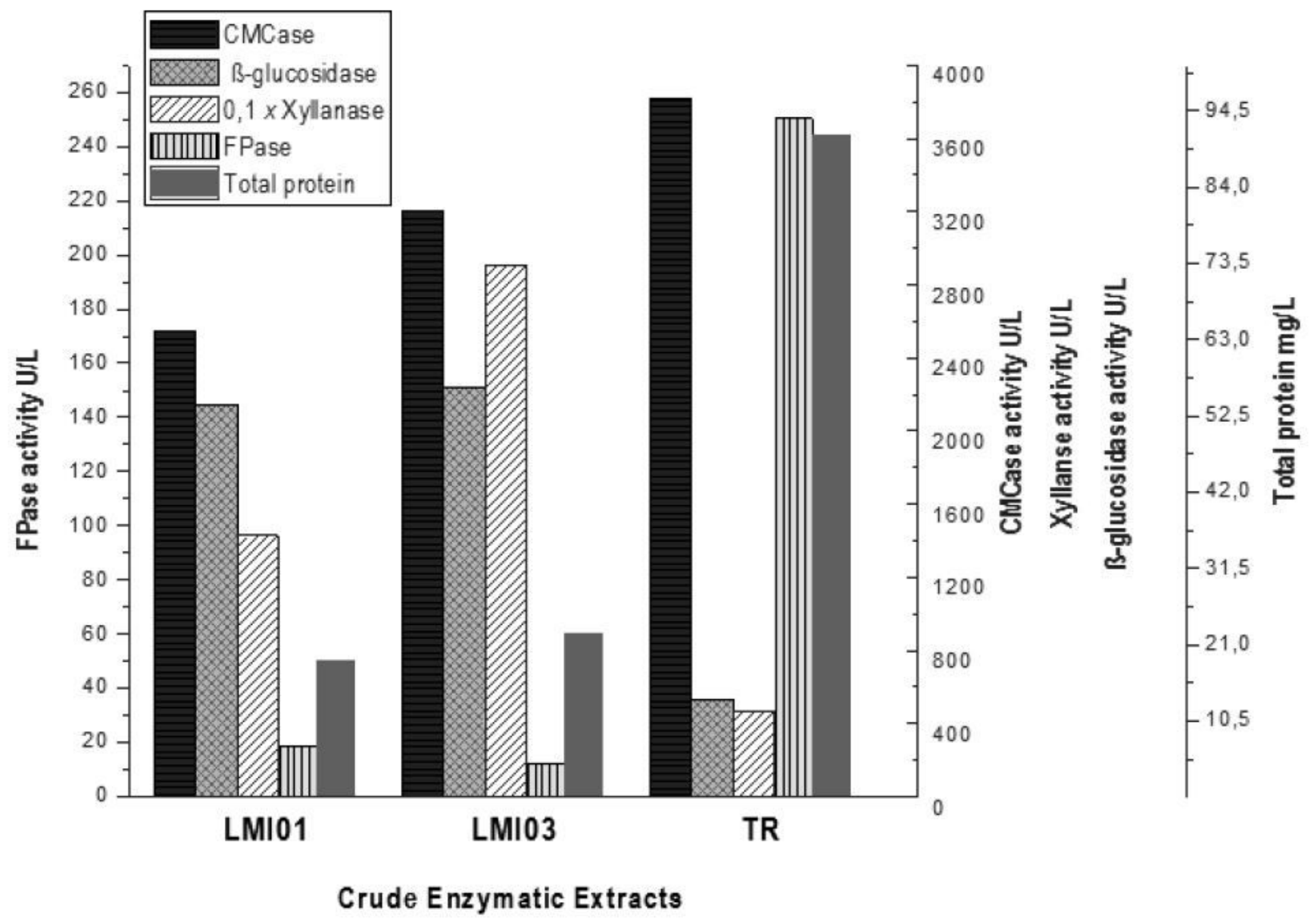

Figure 1

Enzymatic activities and total protein concentration in crude enzymatic extracts, after 72 hours of submerged fermentation, with industrial cellulose pulp as a carbon source 

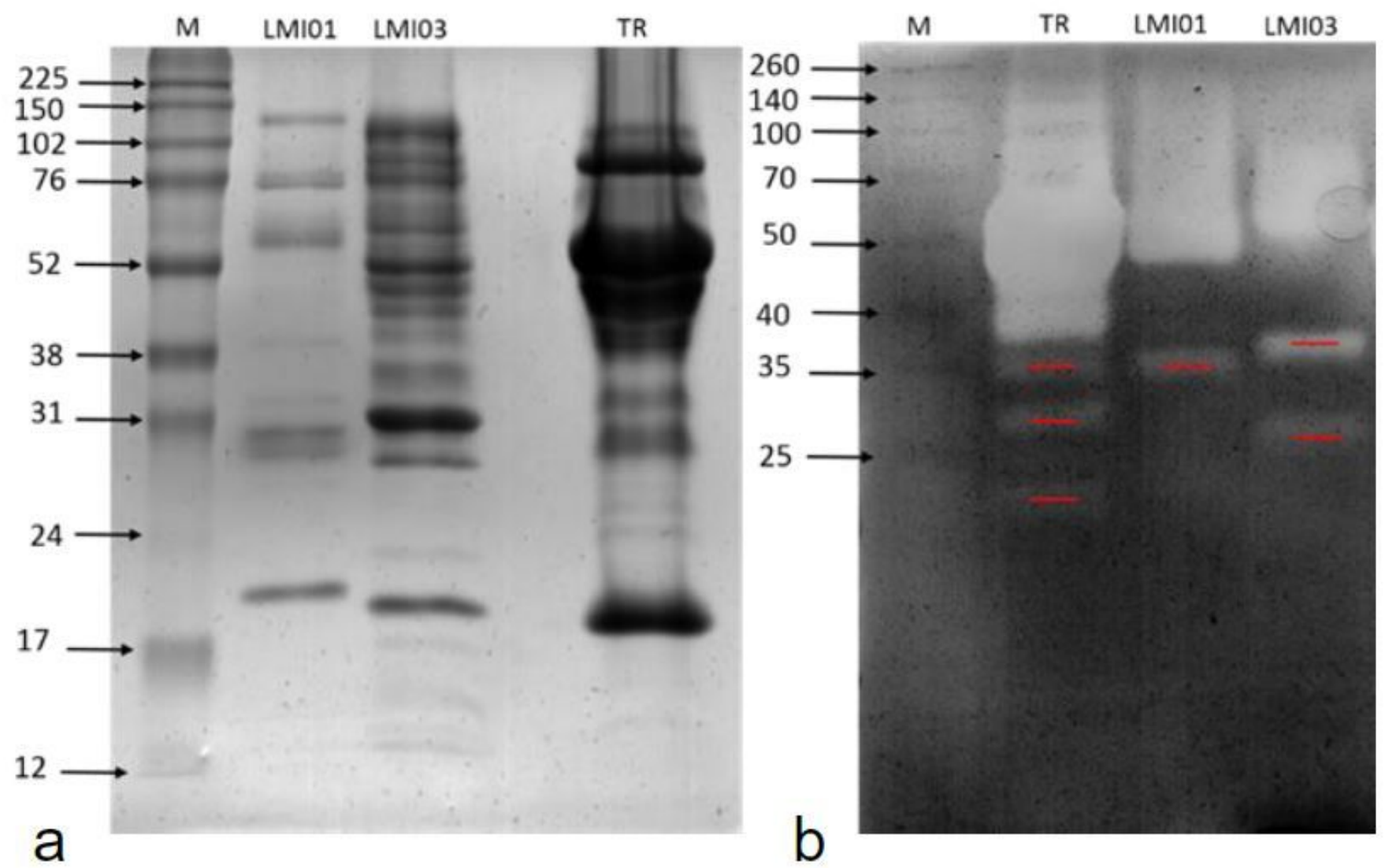

\section{Figure 2}

Electrophoretic protein profile and zymogram for cellulases of the crude extract of fungi. a SDS-PAGE polyacrylamide gel stained with Coomassie blue R-250; M: Molecular weight marker (225kDa to 12kDa). LMI01: P. citrinum $(6 \mu \mathrm{g})$; LMI03: Aspergillus sp $(9 \mu \mathrm{g})$; TR: T. reesei QM9414 $(13.6 \mu \mathrm{g})$. b SDS-PAGE gel zymogram $(0.2 \% \mathrm{CMC})$ stained with $1 \%$ Congo red. M: molecular weight marker (260kDa to $10 \mathrm{kDa})$, samples with a concentration of $5 \mu \mathrm{g}$ of total proteins 


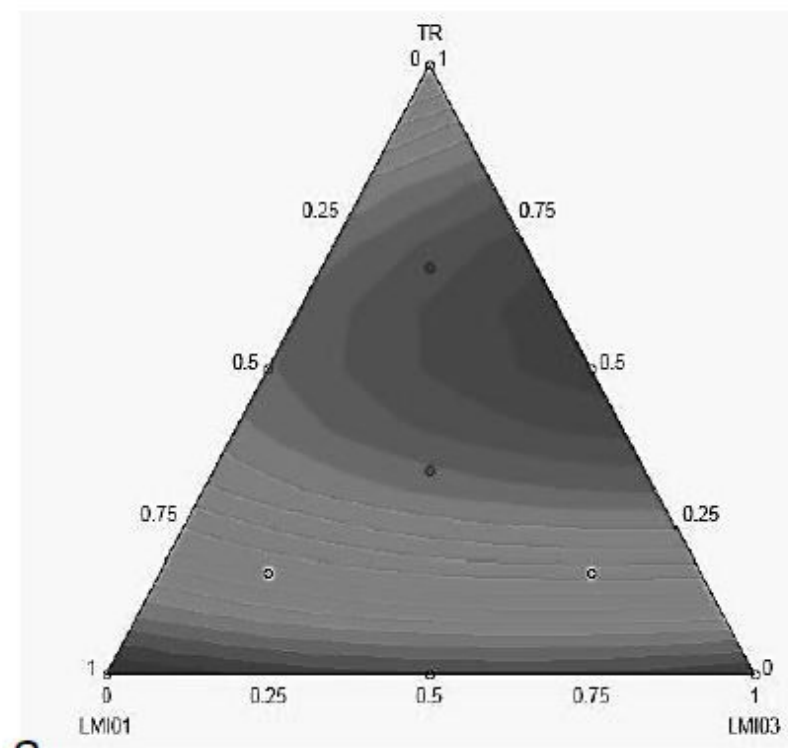

a

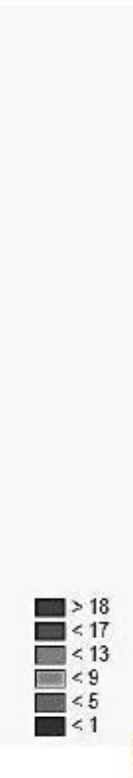

\section{Figure 3}

Contour surfaces for quadratic models generated in the mix design. a AMZ1 cocktail for cellulose pulp hydrolysis; b AMZ2 cocktail for cassava peel hydrolysis

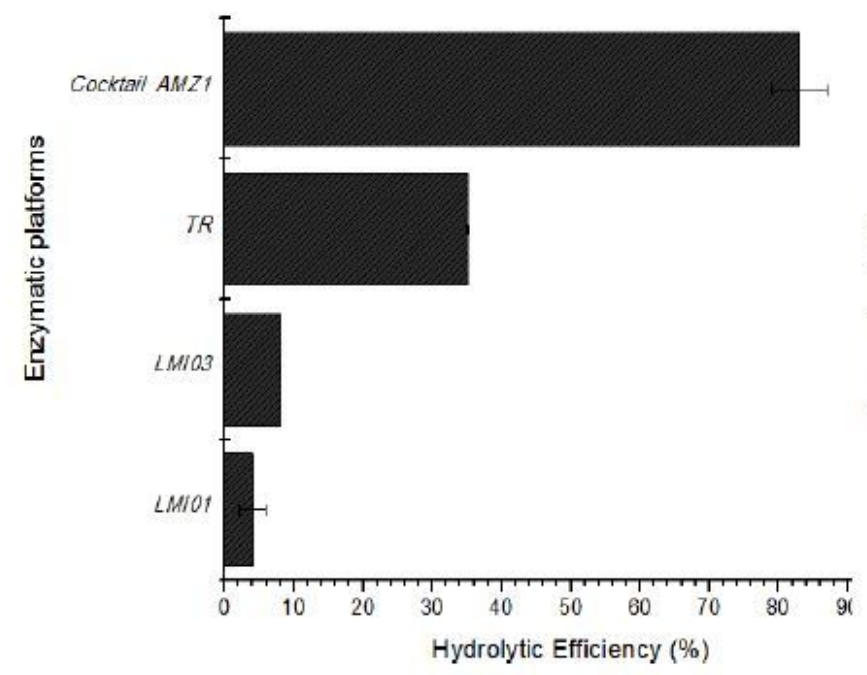

a

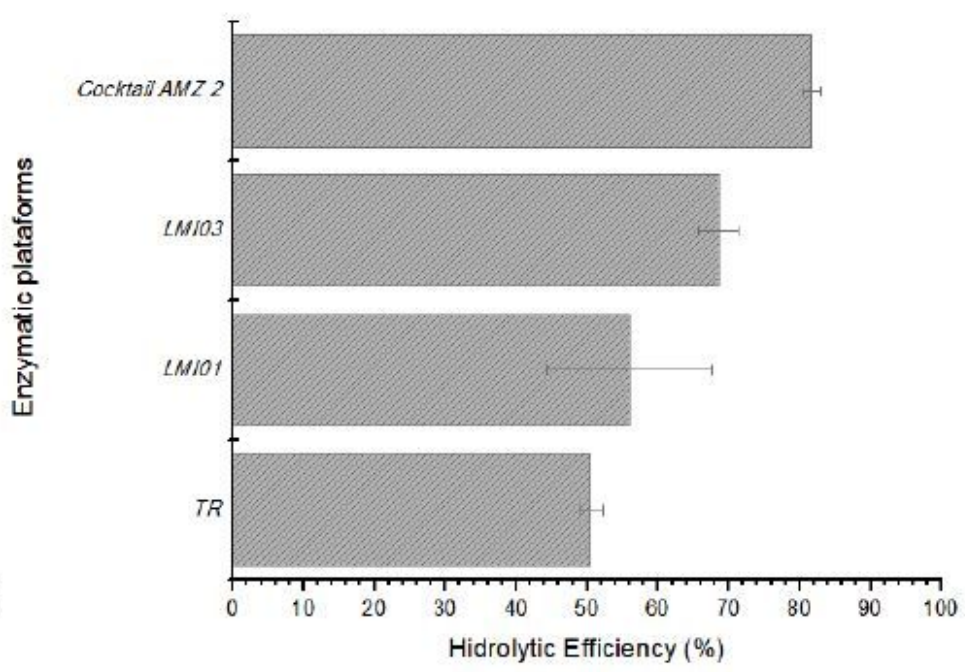

b

\section{Figure 4}

Hydrolytic efficiency of the individual enzyme platforms and of the optimized cocktails, using $15 \mathrm{mg}$ of protein/g of cellulose and $25 \mathrm{~g} / \mathrm{L}$ of solid residue. a hydrolysis of industrial cellulose pulp; $b$ hydrolysis of 
cassava peel. LMI01: P. citrinum; LMI03: Aspergillus sp; TR: T. reesei QM9414; Cocktail AMZ1: 47\% LMI03 + 53\% TR; Cocktail AMZ2: 50\% LMI03 + 25\% TR + 25\% LMI01

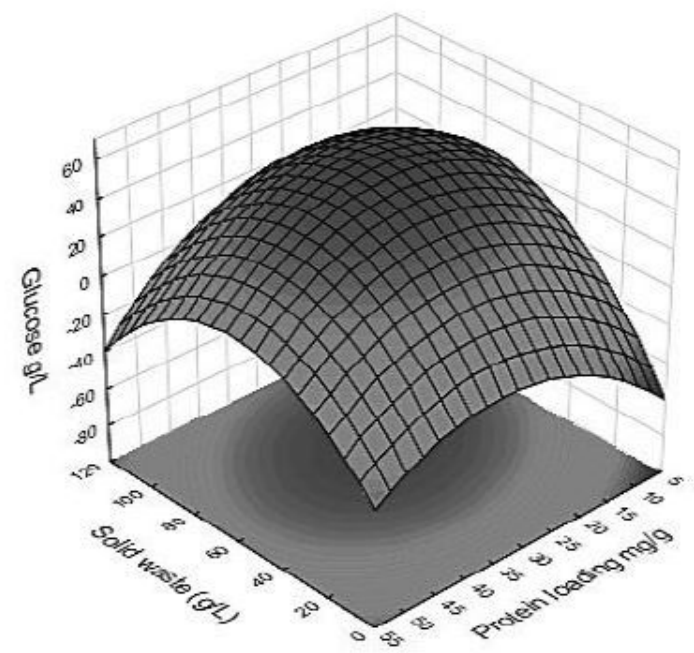

a
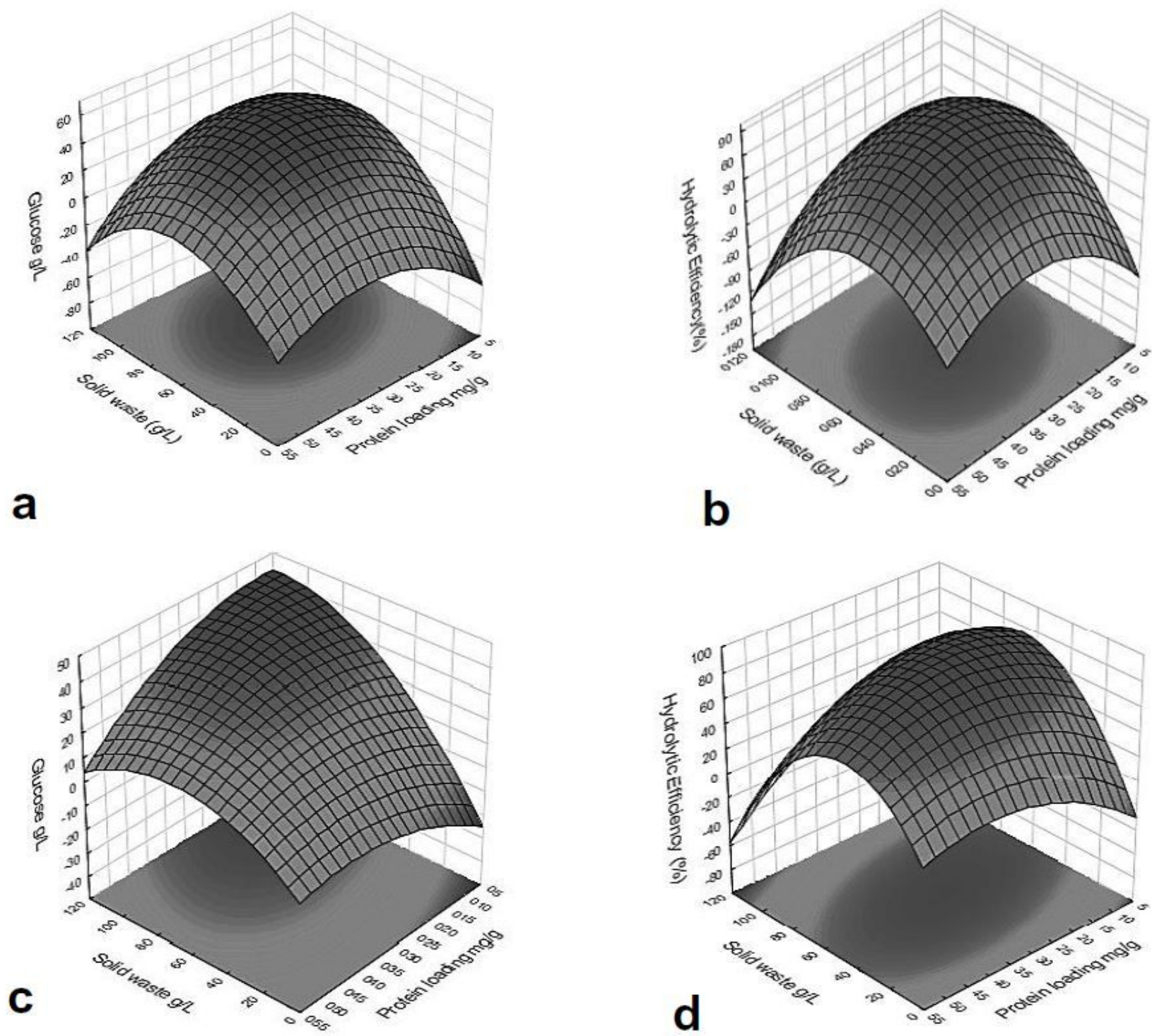

\section{Figure 5}

Response surfaces for glucose released and hydrolytic efficiency as a function of loading solid and protein. a glucose ( $\mathrm{g} / \mathrm{L})$, b Hydrolytic efficiency (\%) to AMZ1 cocktail. c and d glucose ( $\mathrm{g} / \mathrm{L}$ ) and hydrolytic efficiency (\%), to AMZ2 cocktail 

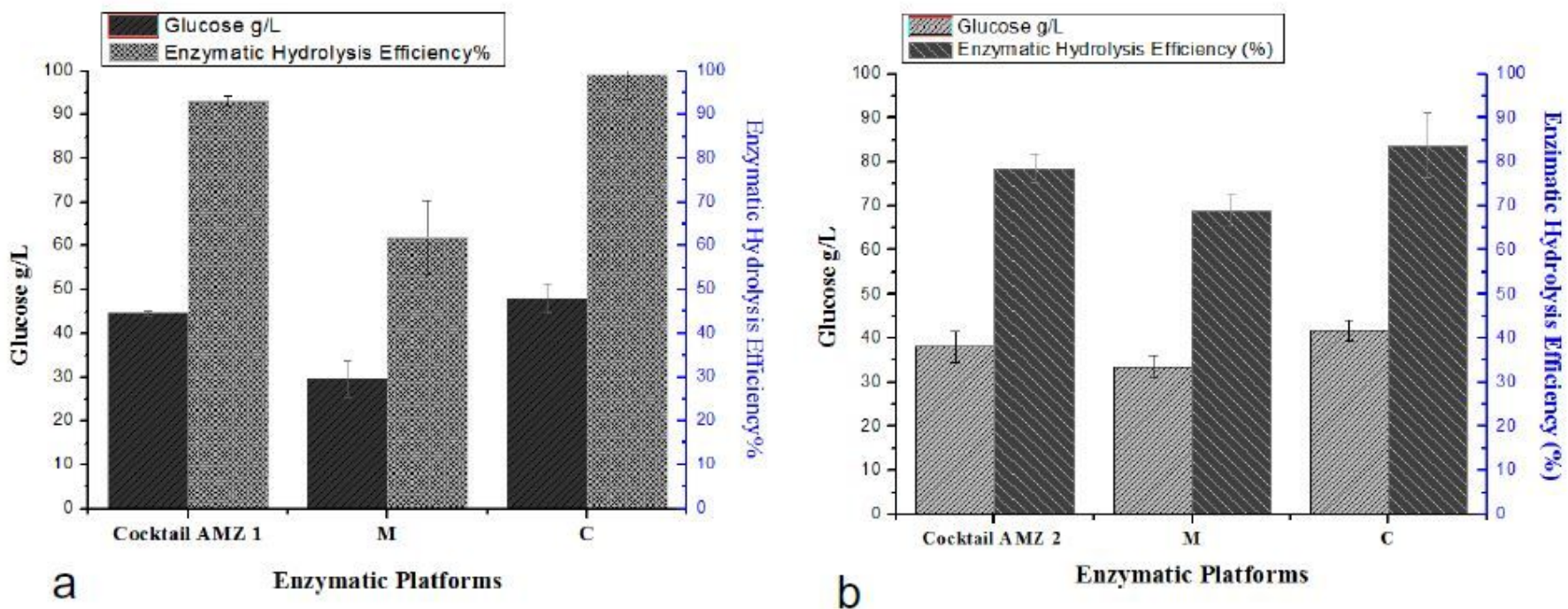

Figure 6

Glucose released (g/L) and hydrolytic efficiency (\%) after $48 \mathrm{~h}$ of hydrolysis at $50^{\circ} \mathrm{C}$. a hydrolysis of industrial cellulose pulp $(52 \mathrm{~g} / \mathrm{L})$ with $30 \mathrm{mg}$ of protein. b hydrolysis of cassava peel $(78 \mathrm{~g} / \mathrm{L})$ with $19 \mathrm{mg}$ of protein. $\mathrm{M}$ and $\mathrm{C}$ : commercial enzyme Multifect ${ }^{\circledR}$ and Cellic ${ }^{\circledR} \mathrm{CTec} 2$ respectively 